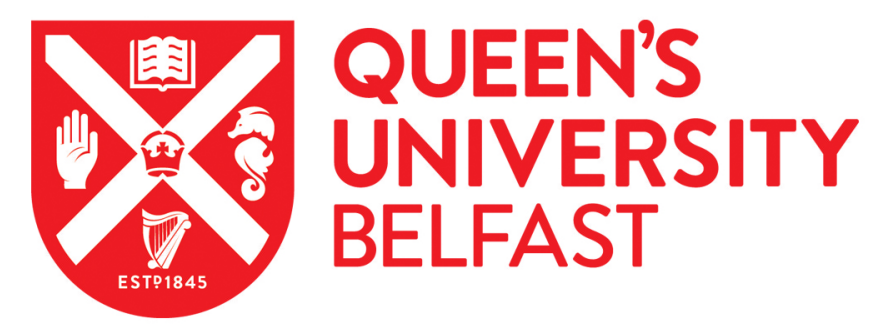

\title{
The ins and outs of microorganism-electrode electron transfer reactions
}

Kumar, A., Huan-Hsuan Hsu, L., Kavanagh, P., Barrière, F., Lens, P. N. L., Lapinsonniere, L., Lienhard V, J. H., Schröder, U., Jiang, X., \& Leech, D. (2017). The ins and outs of microorganism-electrode electron transfer reactions. Nature Reviews Chemistry, (1), [0024]. https://doi.org/10.1038/s41570-017-0024

Published in:

Nature Reviews Chemistry

Document Version:

Peer reviewed version

Queen's University Belfast - Research Portal:

Link to publication record in Queen's University Belfast Research Portal

Publisher rights

(c) 2017 Nature Publishing Group. This work is made available subject to the publisher's terms.

\section{General rights}

Copyright for the publications made accessible via the Queen's University Belfast Research Portal is retained by the author(s) and / or other copyright owners and it is a condition of accessing these publications that users recognise and abide by the legal requirements associated with these rights.

Take down policy

The Research Portal is Queen's institutional repository that provides access to Queen's research output. Every effort has been made to ensure that content in the Research Portal does not infringe any person's rights, or applicable UK laws. If you discover content in the Research Portal that you believe breaches copyright or violates any law, please contact openaccess@qub.ac.uk. 


\section{The ins and outs of microbial-electrode electron transfer reactions}

Amit Kumara\&f, Huan-Hsuan Hsub Paul Kavanaghc, Frédéric Barrièred, Piet N.L. Lens ${ }^{\mathrm{e}}$, Laure Lapinsonniere ${ }^{\mathrm{b}}$, John H. Lienhard Vf, Uwe Schröderg, Jiang Xiaocheng ${ }^{b}$, Dónal Leechc

aDepartment of Chemical Engineering, Massachusetts Institute of Technology, 77 Massachusetts Ave, Cambridge, MA, USA. bDepatment of Biomedical Engineering, Tufts University, Medford, MA, USA. 'Biomolecular Electronics Research Laboratory, School of Chemistry \& Ryan Institute, National University of Ireland Galway, Ireland.

dUniversité de Rennes 1, Institut des Sciences Chimiques de Rennes UMR CNRS 6226, Campus de Beaulieu, 35042 Rennes cedex, France.

eDepartment of Environmental Engineering and Water Technology, UnescoIHE, Delft, The Netherlands.

fDepartment of Mechanical Engineering, Massachusetts Institute of Technology, 77 Massachusetts Ave, Cambridge, MA, USA.

Institute of Environmental and Sustainable Chemistry, Technische Universität Braunschweig, Hagenring 30, 38106 Braunschweig, Germany.

\section{Abstract}

Microbial-electrode electron transfer is a mechanism by which microbes make their living coupling to electronic circuits, even across long distances. From a chemistry perspective, it represents a model platform that integrates biological metabolism with artificial electronics, and will facilitate the fundamental understanding of charge transport properties within these distinct chemical systems and particularly at their interfaces. From a broad standpoint, this understanding will also open up new possibilities in a wide 
range of high impact applications in bioelectrochemical system based technologies, which have shown promise in electricity, biochemical, chemical feedstock production but still require many orders of magnitude improvement to lead to viable technologies. Here we review opportunities to understand microbial-electrode electron transfer to improve electrocatalysis (bioelectricity) and electrosynthesis (biochemical and chemical production). We discuss challenges and the ample interdisciplinary research opportunities and suggest paths to take to improve production of fuels and chemicals at high yield and efficiency and the new applications that may result from increased understanding of the microbial-electrode electron transfer mechanism.

Bio-electrochemical system (BES) can be expressed as the bidirectional electron transports between biotic and abiotic components, where the redoxactive microorganisms or bio-macromolecules act as the catalysts that facilitate the exchange process ${ }^{1}$. A glossary of important terms is provided in box 1. A model system of BES that has been widely studies is the Microbial Fuel Cell (MFCs). Similar to the conventional fuel cell, the microorganisms can transport electrons to the anodes of MFC after oxidizing the electron donors, thus generating the electrical flow toward the cathode ${ }^{2}$. Meanwhile, certain microorganisms are also known for their capability to reduce the electron acceptors such as nitrate, perchlorate or metals in the cathodes ${ }^{3}$. Other BESs such as Microbial electrolysis cells (MEC), Microbial electrosynthesis (MES), Microbial solar cells (MSCs), and Plant microbial fuel cells (PMFCs) also share similar electron transport strategy. These direct electron transport processes created a novel and promising possibility to bridge the fundamental researches in microbiology, electrochemistry, environmental engineering, material science and the applications in waste remediation \& resource recovery, sustainable energy production, and bio-inspired material development. The basic working principles and the applications of these 
different BESs have been comprehensively reviewed by many different groups $4-7$.

\section{Bioelectrochemcial systems}

Enzymatic electron transport process is one of the earliest BES models which received extensive attention due to the interests in development of amperometric biosensors and enzymatic fuel cell in late $20^{\text {th }}$ century ${ }^{8-12}$. In this system, the electrons generated from specific enzymatic reactions can be either directly (tunneling) or indirectly (via foreign mediators) transported to the solid-state electrode and therefore be detected. The direct electron transport of enzyme can only occur within electron tunneling distance of a few nanometers if no foreign mediator is involved ${ }^{9}$. In most cases, the redox centers of enzymes are deeply embedded in the insulated protein matrix which limited the electron transport toward solid-state electrode. Therefore the electron transport efficiency is largely restricted by this less-than-effective electrical coupling. Specific strategies to immobilize enzymes to electrodes are inevitable to facilitate direct electron transfer for practical applications ${ }^{13}$. Furthermore, the three-dimensional structure is essential to the catalytic activity of the enzyme. However, these structures are vulnerable which are very sensitive to the variation of temperature, $\mathrm{pH}$, and chemical components of the surrounding environment ${ }^{14}$. Although the many immobilization techniques (enzyme-electrode; enzyme-conductive support-electrode; enzyme-cofactor-mediator complexes-electrodes) do extend the active time of enzymatic electron transport, the maximum lifetime of the effective enzymatic electron transport system is hours up to day ${ }^{10,15}$. All of these limitations prohibit the application of this BES model in its applications in both energy generation and biosensor.

Unlike isolated enzymatic molecules, certain microorganisms, usually named as electrochemically active bacteria (EAB), are able to self-amend to overcome 
the incompatibilities between the biological/ inorganic interfaces and achieve effective, long-term, and wide-range electron transport. Extracellular Electron Transfer (EET) is the key process that links the solid state electron donors/acceptors and the microorganisms. In the circumstance that soluble electron acceptors, oxygen in most of case, are depleted, EAB are able to transport the metabolism-generated electrons to external acceptors outside the cell. The concept of EET is brought up in early 19's when Potter ${ }^{16}$ and Cohen ${ }^{17}$ demonstrated the electricity harvested from the metabolism of microorganisms. In 1960's, the growing demands in sustainable energy augment the interest in understanding the fundamentals of EET 6 . Following this development, in early 2000's, several different mechanisms have been proposed which suggest that microorganisms can naturally transport electrons to the electron acceptor through both direct and indirect pathways. The direct EET relies on outer membrane cytochromes to couple the internal metabolism with external charge transport, and generally requires direct contact between cell membrane and the solid-state electron acceptors. Additionally, certain $E A B$ are also known for their capability to generate conductive Pili or pilus-like structures under acceptor limited conditions, which serve as an alternative electron pathway to extend the direct EET distance and maximize the transport efficiency. These pili or pilus-like structures are usually referred as microbial nanowires ${ }^{18,19}$. In the case of indirect EET, some EAB are able to secreted redox materials such as phenazines, flavins, and quinones $1,20,21$ to carry the inner electron to diffuse toward the electron acceptor outside. These redox materials first diffuse into the cell to be reduced which carry the electron to the solid state electron acceptor and then be oxidize thus complete the electron transport and transfer back to original form for next duty. Ideally, these redox materials can be utilized repeatedly thus been named as "electron shuttles. ${ }^{1 \prime}$ 
While significant progress has been made in understanding and exploiting EET, the detailed mechanisms, e.g. protein-protein interaction ${ }^{22}$, electron transport inside microbial nanowires ${ }^{23}$ and bacterium-solid state material interaction ${ }^{24}$ are still vague and actively debated. The purpose of this review is to provide an overview of the current state-of-art understanding in bioelectrochemical systems and EET and present the obstacles that need be overcome to accomplish a comprehensive, unambiguous understanding of BES. Some earlier works in applying micro-/nano-technologies in single cell measurements are also introduced in this article which may bring some additional insights to current EET research. These efforts are expected to open whole new possibilities for researchers to design and optimize the BES, thus maximizing the EET efficiency for future applications.

\section{Extracellular Electron Transfer at Bioanodes}

For EET microorganisms, outward EET (electron transfer from microorganisms to extracellular electron acceptor) is a natural process for microorganisms to complete the respiration when there is limited access of soluble electron acceptor in the environment. In the artificial bioelectrochemical systems, most for energy harvest (e.g. MFC), microorganisms performing this outward EET act as the catalyst in the fuel cell anode; therefore, they are named as Bioanodes.

The bioanode studies primarily focus on the dissimilatory metal reducing bacteria (DMRB). The DMRB can colonize on the inert electrode surface (carbon-based or gold) with positive potential bias (to serve as the electron

acceptor). After colonization, DMRB start the metabolism and EET process for proliferation and form electrical connections between both bacteria-bacteria and bacteria-electrode. These connections can eventually construct an electrically conductive biofilm comprised of cells and extracellular substances 
that can exceed $100 \mu \mathrm{m}$. Recently, this extraordinarily long range of biological electron transport (i.e electron transports (respirations) in other biological systems are limited to molecule-length scales ${ }^{25}$ ) attracts enormous attentions. Many studies have suggested that the redox protein such as c-type cytochrome (c-cyt) and iron sulfur protein presented in the EET system of DMRB are the key elements to link the electron transport across multiple length scales ${ }^{1,23,26}$. Most EET research to date has been focused on two prototype strains of DMRB - Geobacter and Shewanella. Other DMRB such as Proteus vulgaris, Pseudomonas sp., Klebsiella pneumonia, Bacillus subtilis, and Corynebacterium sp. etc. can also perform EET, yet the fundamental mechanisms are still lack of systematic studies ${ }^{27}$. As mentioned in previous sections, researchers concluded three possible models for EET (Fig. 1): i) EET through outer membrane redox protein c type cytochromes (c-cyts) and other redox proteins, such as multi-copper proteins (OmpB and OmpC); ii) EET through pilus-like structures (nanowires) and iii) EET by utilizing extracellular or self-excreted small molecule as the electron shuttles $20,21,28,29$.

Both Geobacter and Shewanella use c type cytochromes (c-cyts) to transport electron to electron acceptor. C-cyts are the multi-heme containing proteins. Geobacter sulfurreducens contains 111 genes encoding c-cyts. 73 of these ccyts contain two or more heme groups, with one containing as many as 27 heme groups. Similarly, Shewanella oneidensis has 39 genes encoding c-cyts and 14 of them contain 4 or more hemes. The detailed structures of these ccyts have been discussed in previous reviews ${ }^{30}$. Through the regulation of gene expression, the key c-cyts of both bacteria models in performing EET have been identified and studied. In Geobacter, outer membrane EET is contributed by a variety of outer membrane c-cyts (OMCs), including OmcB, OmcE, OmcS, OmcZ. Mehta et al. suggested that OmcE and OmcS can facilitate ET to the type IV pili (discuss in next paragraph) for long-range electron transport while $\mathrm{OmcB}$ is the intermediary electron carrier from 
periplasm to other $\mathrm{OMCs}^{31}$. However their following research proposed different mechanisms that i) OmcS and OmcE might also be able to directly transfer electrons to the electrodes and ii) the OmcB is only important in iron reduction but not essential in $\mathrm{EET}^{32}$. Lately, by combining the electrochemical and genetic approaches, Richter et al. from the same group concluded that: i) OmcZ is critical to outer membrane EET; genetic deletion of OmcZ in Geobacter resulted in $>90 \%$ decrease in current ${ }^{33}$; ii) OmcB mediates the electron transport from periplasm to other OMCs; iii) OmcS support the outer membrane EET and; iv) OmcE is not participate in EET ${ }^{34}$.

The functions of c-cyts in the EET of Shewanella were also studied by genetic engineering approaches. Scientists conclude that the EET of Sehwanella is accomplished by series of protein-protein interactions. First, CymA transport electrons generated from bacteria metabolism to the terminal reductases in periplasm. This step is considered inevitable in Shewanella EET as a deletion of CymA gene caused around $80 \%$ decrease in current generation ${ }^{26}$. Next, the reductases pass the electron to outer membrane protein such as MTRs and OMCs. These outer membrane proteins then transport electron to electron acceptors or electron shuttles to finish the EET process. MtrC is considered as one of the most important outer membrane proteins in the EET process of Shewanella, deletion of MtrC can lead to $>90 \%$ of current decrease ${ }^{35}$. Detailed functions of each c-cyts involved in the outer membrane EET and the characterization methods are recently reviewed by different groups $22,26,36,37$.

The effective range of direct EET through outer membrane c-cyts is generally limited to nanometer scale ${ }^{38}$, which is similar to enzymatic systems. For long range EET, Shewanella can self-excrete some small molecules such as flavin and other quinone-type molecules to mediate wide range transport, which cannot be achieve by Geobacter 20,21,38,39. However, the function of these small molecules in Shewanella EET remains unclear and several hypotheses have been proposed. including i) flavin serves as the EET cofactor which 
facilitate EET process of c-cyts ${ }^{40}$; and ii) flavin is the electron shuttle which directly perform EET on outer membrane ${ }^{20}$.

Interestingly, both Geobacter and Shewanella are able to perform direct long range EET via self-assemble the c-cyts and form conductive pilus-like structures which can grow up to tens of micrometers. In Geobacter, the microbial nanowires (type IV pili) are found directly connecting the inner membrane to the outer electron acceptor. Other protein like OMCs may transport electron to electron acceptor ${ }^{22}$ through type IV pili. The presence of type IV pili is found to be critical for biofilm to maximize the EET efficiency ${ }^{19}$. However, the underlying mechanisms of charge transport are still controversial and actively debated ${ }^{41,42}$. The "metallic like model" was proposed by Malvankar et al. ${ }^{43}$, which suggest that the electron are transported through the $\Pi-\Pi$ interactions of aromatic structures in type IV pili similar to the synthetic conducting polymers $43-45$. Their results demonstrated that the conductivity of type IV pili is both temperature and gate voltage dependent which is similar to the nanostructured organic semiconductors ${ }^{44}$. However, other results of electrochemical characterizations of Geobacter biofilm suggested that electron is transported through the electron hopping mechanism. Researchers developed a "superexchange model" based on this mechanism - similar to the redox polymers, electron is transported through a series of redox reactions of the discrete redox cofactors contained inside the type IV pili such as heme of c-cys ${ }^{46,47}$. Cyclic voltammetry (CV) of the Geobacter biofilm supports this mechanism by: i) at slow scan rate, the sigmoidal shape of CV curve demonstrates that the electrochemical activities on the biofilm follow the electrode catalytic (EC) reaction scheme which shows that the EET is coupled with redox cofactors ${ }^{48,49}$; (ii) in the absence of electron donor condition, the distinguishable symmetric CV peaks in both forward and backward scanning indicate the EET is a charging-discharging (pseudocapacitance) reactions of redox cofactors in the biofilm ${ }^{34,49-51 ;}$ iii) 
Multiple peaks on the CV curve indicate there may be multiple cofactors involved in the electron transport ${ }^{34,51}$. Other sophisticated bio-electrochemical characterizations ${ }^{52,53}$ and charge storage measurements also support this hypothesis ${ }^{54}$.

In Shewanella, the microbial nanowire is first observed and electrically characterized using scan tunneling microscopy in 2006 by Gorby et al. ${ }^{18}$. The conductivity of the nanowire and the main contributing component - c-cyts is also confirmed in the same work. The mutants deficient in c-cyts can only produce poorly conductive nanowires. To date, evidences have suggested that in the Shewanella nanowire, electron transfer via electron hopping through a cytochrome network 23,55-57. Recent study of Pirbadian et al. further demonstrated that the Shewanella nanowire is the outer membrane and periplasmic extensions but not the pilin-based structures which also support the electron-hopping (cyts redox reactions) electron transport mechanism ${ }^{56}$.

The application of bioanodes to date has been largely limited by its very low power density, which can be attributed to (a) the limitation of the natural metabolic rate of DMRB; (b) the restriction of cytochrome based cross membrane EET and (c) the ineffective EET within the evolutionally developed electron transport pathways, especially at large length-scales. Several strategies have been proposed to overcome this key limitation: i) exploiting synthetic biology: the expression of specific genes which regulate the production of electron shuttles or electron transfer protein can be in the DMRB thus promoting the EET efficiency. For example, the synthetic flavin biosynthesis pathway from Bacillus subtilis was expressed in Shewanella MR1 which lead to 25.7 times more flavin secretion than wild-type Shewanella and consequently 13.2 times increasing in current production ${ }^{58}$. Similarly, the expression of five riboflavin synthesis genes in E. coli BL-21 was reported to induce a 9.5 times increase in EET outcome ${ }^{59}$ and the overexpression of the NAD synthetase gene in $P$. aeruginosa enhanced the current production for 
more than three times ${ }^{60}$. ii) Facilitating cross membrane EET by conjugated oligoelectrolytes (COE): COEs are the water-soluble oligomers with delocalized electronic structure and pendant groups. Certain COEs are able to spontaneously "insert" and align within the bacteria membranes which facilitate the electrons to transfer through this lipid bilayer. 4, 4'-bis (4'-(N, $\mathrm{N}$-bis (6"-(N, N, N-trimethylammonium) hexyl) amino)-styryl) stilbene tetraiodide (DSSN) is one of the most common used conjugated oligoelectrolytes in bacterial EET studies which shows negligible toxicity effects to bacteria ${ }^{65}$. Previous research suggested that both cytochrome-based direct electron transfer and flavin-based mediated electron transfer of Shewanella MR-1 can be promote by the addition of DSSN65. Moreover, a 25-fold improvement in E-Coli based MFC power density can also be obtained by adding the DSSN 66. However, the functions of COE in the facilitation of bacterial EET are under debate ${ }^{67}$. iii) Facilitating EET through hybrid electron pathways. Various nanoscale conducting/semiconducting materials, including carbon nanotubes ${ }^{61}$, graphene ${ }^{62}, \mathrm{Fe}_{2} \mathrm{O}_{3}{ }^{63}$ and $\mathrm{FeS}^{64}$ nanoparticles, have been formulated and seamlessly integrated with the natural biofilms, which have shown significantly improved EET at both cell/electrode and cell-cell interfaces.

In summary, there are many milestones of bioanode researches are accomplished in last decades as summarized in box 2 . The genetic engineering approaches provide extensive scientific evidences of the functions of individual proteins in EET processes. The applications of novel microscopies such as scanning electron microscope (SEM), atomic force microscopy (AFM) and scanning tunneling microscope (STM) revealed the unique structural, morphological and electrical properties of key EET components such as whole biofilm, outer membrane cytochromes ${ }^{68}$, and microbial nanowires. The electrochemical studies concluded the possible mechanisms of how the electrons are transported in the bacterial EET system. The recent advancement of micro-/nano-technologies has provided additional insights 
about EET under controlled microenvironment and across multiple biological length scales (Figure 2). Li et al. demonstrated the measurement of Geobacter cultured in microfluidic device $(L=20 \mathrm{~mm}, W=0.5 \mathrm{~mm}, \mathrm{H}=0.1 \mathrm{~mm})$. This small size Geobacter biofilm demonstrated rapid respond (21 minutes) to ambient environment changes as compare with bulk biofilm (6 hours). This allows relatively high-throughput experiments in study the effect of various stimuli (e.g. $\mathrm{O}_{2}$ and anthraquinone disulfide (AQDS)) in current generation of Geobacter biofilm. Their results further confirm the finding at biofilm levels that i) the minor toxicity of short term oxygen exposure to Geobacter; and ii) AQDS can be used as the electron shuttle for Geobacter EET ${ }^{69}$. Following the similar strategy, many micro-scale MFC and biosensors are developed ${ }^{70}$. Gross et al. achieve the measurement of EET current of single Shewanella in vivo by their sophisticate device which combined infrared optical tweezers, indium tin oxide (ITO) microelectrodes ${ }^{71}$. Their measurements suggest that the EET current of single Shewanella is in the range between $15-100 \mathrm{fA}$ as well as confirming the important role of c-cyts in Shewanella EET. This approach not only provides the information of the current generation of single Shewanella EET which can be used to determine the maximum current output of Shewanella biofilm; but also, it brings the in situ studies of the electron transport mechanism down to single bacterium level which is expected to solve some current debates such as the functions of Flavin and nanowire. Jiang et al. exploited a nanotechnology-enabled platform and a bottom-up approach to tackle EET at single- through multi- bacterium levels ${ }^{72,73}$. Nanostructured electrodes with controlled cellular interfaces have been designed to unambiguously demonstrate EET mechanism in both Geobacter and Shewanella. The real-time longitudinal monitoring of localized current generation and cell-electrode interaction further provided alternative insight about EET that is difficult to achieve in population-level experiments, such as the quantized current "steps" as individual cells initially attach to electrode, 
as well as the dramatic current increase as cells get closely packed and form into electrically-connected networks.

Generally, these emerging cell-measurement techniques are expected to open up new possibilities for precisely probing and regulating electron transport at bioanode interface ${ }^{74}$ and elucidate the fundamental limits and factors determining bioelectrical power extraction, which will in turn help the design of more efficient BES.

\section{Microbial biocathode}

Lithotropic microbes have long been known to exploit iron oxidation for growth (1). Certain sulphate-reducing microbes, for example, use electrons, or electron carrier intermediates, harvested from solid iron as reducing equivalents for energy generation (2). This process, commonly referred to as 'biocorrosion', presents a considerable challenge to the maintenance of ironbased installations, such as gas pipelines, located in suboxic sulfur rich environments (2). Although a comprehensive understanding of biocorrosion remains elusive, three metal oxidising mechanisms are proposed; i) microbial consumption of 'cathodically generated' $\mathrm{H}_{2}$ at the metal surface ii) chemical corrosion by biogenic $\mathrm{H}_{2} \mathrm{~S}$, and iii) direct uptake of electrons from the metal (2). The third, and arguably, most interesting mechanism from an ET point of view, was proposed for sulphate-reducing Delsulfobacterium- and Methanobacterium-like microbes which were shown to accept electrons from solid iron at a rate unachievable by $\mathrm{H}_{2}$ scavenging alone (3). Although a more direct route for electron uptake is thus implied, the complete ET mechanism remains unsolved as the exclusion of $\mathrm{H}_{2}$ involvement in this process has yet to be verified (2).

At about the same time that biocorrosive 'DET' mechanism was first proposed, Geobacter sp. dominated biofilms were shown to accept electrons directly from a solid graphite electrode for respiration (4). Subsequent 
Geobacter sp. (4) and Shewanella sp. (5) pure culture studies showed that both organisms, whilst forming thinner films than their bioanodic counterparts (6), could directly harvest electrons from electrodes. Genomic analysis revealed that a periplasmic monoheme cytochrome, $\mathrm{PccH}$, is essential for electron uptake by $G$. sulfurreducens (6), though gaps remain in the identification of additional proteins required for ET across both membranes. Significantly, PcCP is not required for EET to electrodes showing that two distinct ET pathways are utilised by G. sulfurreducens for inward and outward electron flow (6). In contrast, the OmcA-MtrABC respiratory pathway of Shewanella $s p$. is capable of facilitating electron flow in both directions (5).

The ability of microbial biocathodes to reduce low value, or polluting, reactants to higher value, or less-harmful, products is of great economic and environmental benefit (7). Reduction of nitrates (4), chlorinated solvents (8) and toxic metal ions $(9,10)$, by Geobacter sp. $(4,8,10)$ and Shewanella $s p$. (9) biocathodes has highlighted their potential application in the treatment of contaminated environments (11). The inability of heterotrophic Geobacter $s p$. and Shewanella sp. to fix carbon, however, limits their application in microbial electrosynthesis (12). Autotrophic microbes, on the other hand, which utilise energy from inorganic chemical reactions (chemotrophs) or light (phototrophs) for carbon fixation, and can adapt to use an electrode as an electron source for growth (electrotrophs) are much more amenable. Cathodic biofilms of acetogenic bacterium Sponosa ovata, for example, were shown to convert $\mathrm{CO}_{2}$ and electrons, supplied solely from an graphite electrode, to acetate with a > $85 \%$ electron conversion efficiency (13). Other identified acetogenic electrotrophes include various Sponosa (14) and Clostridium (14, 15) species and Mororella thermoacetica (14). However, little is known about the electroaceteogenic ET pathways utilised by such microbes. Conversion of electrons and $\mathrm{CO}_{2}$ to methane by Methanobacterium sp. dominated biocathodes has also been demonstrated (16). Although DET from the 
electrode to the biofilm was initially speculated as the underlying ET mechanism, recent evidence shows that Methanobacterium sp., secretes proteins which can catalyse $\mathrm{H}_{2}$ formation at the electrode surface which may be rapidly consumed by the organism (17). Biocathodes composed of Rhodopseudomonas palustris, a natural $\mathrm{Fe}(\mathrm{II})$-oxidising prototroph, have been shown to fix $\mathrm{CO}_{2}$ under both light and dark conditions (18). The operon $P i O A B C$, encoding an OM porin, a periplasmic cytochrome and Fe-S cluster protein, was essential for $R$. palustris electrode growth (18). It is likely that numerous other, so far unharnessed, Fe(II)-oxidising autotrophs may be utilised at biocathodes for carbon fixation.

Although much progress has been made in microbial electrosynthesis, a deeper understanding of EET pathways is necessary to improve rates and yields. Many microorganisms which induce iron corrosion have also been shown to harvest electrons from electrodes, either directly (19) or indirectly (17). Whist detrimental to solid iron, such corroding biofilms, if harnessed at an electrode, may sustain rapid formation of added value products indefinitely. In addition, mechanistic insights gained from biocorrosion studies may benefit the advancement of microbial electrosynthesis applications, particularly with regard to ET pathways necessary for rapid electron uptake (17). Advancements in bio-engineering of autotrophs to produce bulk chemicals and biofuels form syngas (20), may be extended to electrotrophs, with an initial report showing the potential of an engineered Clostridium ljungdahlii strain for butyrate production (21). Whilst in their early stages of development, microbial biocathodes, due to their self-generating properties, may also overcome the stability limitation of more traditional enzyme electrodes as electrocatalysts for reduction reactions (22). However, for successful implementation of microbial biocathodes as alternatives to existing technologies, improvements in the substrate diversity, turnover rate and product yield is essential. 


\section{Surface chemistry in Microbial BES design}

Understanding the fundamental chemistry of cell attachment, interconnection, and charge transport at electrode interface is essential to achieve rational optimization of BES technologies and represents a rich multidisciplinary research frontier. The physico-chemical property of a surface, such as composition, roughness, charge density, or hydrophobic/hydrophilic and lipophobic/lipophilic nature, is known to influence biofilm formation ${ }^{93}$. Furthermore, the molecular structure of the surface functional groups could be closely associated with electron transfer rate at biofilm-electrode interface and further interfere with the natural EET process. Although un-modified carbon-based electrodes are the most widely used substrates for formation of electrocatalytically active biofilms, researchers have recently begun to probe the effect of surface treatments on biofilm performance in an effort to enhance the biofilm-electrode interaction. As noted previously Shewanella, will not form an electrocatalytic biofilm on gold, highlighting the importance of the nature of the electrode surface with respect to microbial BES applications.

An important and easily addressable factor for promoting biofilm development is increased surface roughness, as near-atomically flat surfaces generally take more time to be colonized than those with roughness at least on the order of magnitude of the average bacterium size (ca. 1 micrometer) ${ }^{78}$. Highly porous rough electrode materials thus show significantly improved biomass concentrations (mass of cells and extracellular substances per unit projected/geometric surface area) and current generation compared to smooth and planar electrodes 76,79 . Other factors that can influence microbial electrode colonization/biofilm formation include the nature, amount and physico-chemical properties of the chemical group(s) present on the electrode surface. Studies have demonstrated that electrode pretreatment (heat, acid, plasma treatment or less frequently, uncontrolled chemical grafting) has an effect on biofilm development and performance. For example, pretreatment 
of graphite electrodes by electrochemical oxidation in sulfuric acid affects the microbial composition of biofilms formed on graphite electrodes imbedded in marine sediment ${ }^{28}$. An increased nitrogen to carbon ratio of carbon-based electrodes appears to favor biofilm development and electrocatalytic performance ${ }^{80}$. There is little indication provided, in these initial studies, on the physical, chemical or biochemical basis for the effect on biofilm development and performance; nor is the amount and/or the nature of the modification precisely known. Studies, outlined below, on deliberate controlled modification of surfaces, can be undertaken to increase knowledge of the surface chemistry required to favor biofilm development and EET.

The first test of this effect for BES involved grafting of aminophenyl functional groups onto graphite and subsequent use of these modified graphite electrodes as anodes in microbial fuel cells, with variations to this grafting approach shown in Figure 5. This electrode modification results in reduced colonization time and improved electrocatalytic performance observed over un-modified electrodes 37,82 . The reason for the beneficial effect is not unequivocally established, but can be inferred in part to the tuning of the charge and hydrophilicity of the carbon electrode surface. Electrodes grafted with negatively charged carboxylate surface groups result in decreased colonization and improved electrocatalytic performance of bioanodes, presumably due to electrostatic repulsion between the charged electrode surface and the similarly charged Geobacter bacterial surface. In contrast, triphenylphosphonium functional groups on electrode surfaces proved beneficial with respect to colonization and electrocatalytic performance, producing denser biofilms that are enriched in Geobacter species. This result is intriguing since effect of surface modification appears not to be confined to the biofilm/electrode interface but propagates into the biofilm itself. The triphenylphosphonium group is widely used as a drug carrier functionality as its positive charge and lipophilicity is suitable for solubilization within and thus 
crossing cell or mitochondrial membranes ${ }^{83}$. It is thus likely that the effect of surface chemistry on biofilm response is a complex combination of electrostatic interaction and lipophilicity. Additional studies demonstrate phenylboronic acid group on electrodes, presumably through specific binding with carbohydrates on the outer membrane of cells ${ }^{84}$, significantly diminishes the time required for biofilm colonization in a mixed culture inoculum. The resulting bioanodes perform better than unmodified electrodes, consistent with the carbohydrate-boronate affinity hypothesis, although a more subtle combination of interactions with outer membrane of bacteria and exopolymeric biofilm scaffold cannot as yet be ruled out. A recent study confirms enhanced current produced by Shewanella loihica biofilms formed on modified indium tin oxide electrodes with increased degree of wettability. This is attributed to a shift in the redox potentials of outer membrane cytochrome heme(s) brought about by the more polar environment thus resulting in increased current at the same applied potential for the biofilms ${ }^{85}$.

Beyond cell attachment, a more promising and less well explored area are surface modifications specifically intended to improve electron transfer rates between biofilms and the electrodes. There is a wealth of information on controlling protein interactions with surfaces ${ }^{98}$ and on optimizing electron transfer between isolated redox proteins, particularly $c$-Cyt, and various electrode materials ${ }^{87}$. It has been shown that, for $c$-Cyt, not only is the distance between the heme and the electrode important but also the orientation of the heme group relative to the electrode ${ }^{19,88}$. Heme groups orientated parallel to the surface display greater ET rates compared to perpendicular heme groups, suggesting that ET pathway through the heme axial ligand is preferential compared to ET through the porphyrin ring 89 . Surface wettability was identified as a key parameter for heme orientation with parallel orientation favored on a hydrophilic surface whilst perpendicular orientation favored on a hydrophobic surface. This observation may partially 
account for the enhancement of electrocatalytic biofilm performance observed on hydrophilic surfaces and highlights the potential mechanistic insights that may be gained from such studies. In addition to modifying electrode surfaces, use of redox and/or conducting polymers ${ }^{90-91}$ and/or nanomaterials could also be explored to electrically wire microorganisms to electrodes, including connecting metabolic processes inside cells to electrodes outside cells in a manner analogous to that used to wire redox enzymes to electrode surfaces ${ }^{92-}$ 93. This is an under-exploited approach to engineering microbial BES which may expand the scope of useable microorganisms to those with interesting/useful catalytic properties but that lack ability to electrically wire themselves to electrodes ${ }^{94-95}$.

Although the EET mechanisms may be different, surface modifications that promote biofilm formation on anodes tend to benefit biofilm formation on cathodes as well. For instance, introduction of positive charged functional groups at carbon cloth electrodes significantly improves formation and performance of Sporomusa ovate films used for electrosynthetic production of acetate in a microbial electrolysis cell96-97. Carbon nanotube (CNT) modified electrodes prove superior to planar electrodes for mixed consortia biofilm formation and acetate production rates ${ }^{75}$. This improvement was attributed to more favorable microbial adhesion provided by the CNT network and not simply due to increased surface area.

An important issue in developing surface engineering approaches to optimization of microbial BES will be clarification of the effect of surface modification on the physico-chemical properties of the electrode and the impact on biofilm development and its subsequent electrical/catalytic properties. To this end, studies on ET to redox proteins on such surfaces will continue to provide mechanistic insights into the effect of surface modifications. Approaches to effectively 'wire' microbial layers to the electrode surface through the use of chemical modifications and addition of redox 
mediators to surfaces should be investigated. This represents a significant challenge as defined surface modifications capable of specifically binding such species have yet to be identified.

\section{Chemistry considerations of other BES components}

Microbial bioanodes need to be partnered with a cathode to operate as a microbial fuel cell or microbial electrolysis cell. Oxygen in air is the most plentiful (and cheap) oxidant. Electrocatalytic bacteria however require anaerobic conditions to encourage electron transfer to the electrode. Most bioanodes therefore are typically coupled with abiotic oxygen-reducing cathodes using a separator such as Nafion, either as a separate component or integrated with the cathode as an air cathode, to isolate the bioanode from oxygen while maintaining ionic continuity between the electrodes. Oxygen reducing cathodes perform poorly at neutral $\mathrm{pH}$ conditions required by electrocatalytic bacteria ${ }^{102}$. Moreover, separator ion permeability can be limited by relatively low temperature conditions and complex electrolytes required by electrocatalytic bacteria. Approaches that identify electrocatalytic organisms able to operate under conditions more beneficial for oxygen reduction at cathodes and/or ion transport through separators, as well as approaches to protect existing electrocatalytic organisms under such conditions, could have significant impact on the development of more effective BES. Development of cathodes able to operate optimally at neutral $\mathrm{pH}$ and separators able to operate optimally at lower temperature could also have significant impact. Analogous requirements exist for microbial biocathodes which need to be partnered with an anode to operate. Here bulk water oxidation appears to be the dominant anode reaction and catalysts able to perform this reaction at fast rates and (ideally) low overpotential under 
physiological conditions required by biocathodes are sought for improved utilization.

\section{Outlook}

An essential component to improving low reaction rates and yields of bioelectrodes is improved understanding of the composition and spatial organization of all the extracellular substances under physiological relevant conditions. While Raman microscopy has been utilized to determine presence of redox proteins in Geobacter bioanodes at the single cell level ${ }^{103}$, imaging at the single-molecule level is required. Complementary approaches for identification, isolation and characterization of the key redox pathways for EET, including genetic mutation, differential proteomic and metabolomic studies, structural studies using crystallography and NMR on isolated protein and complexes, are required. Application of other advanced in-situ analytical tools (such as conducting-probe atomic force microscopy, electrostatic force microscopy, electrochemical-surface plasmon resonance and electrochemical quartz crystal microbalance) to be applied under physiological relevant conditions (i.e, performed on living biofilms) will elucidate conductive pathways. Approaches to wire microbial layers to the electrode surfaces through the use of chemical surface modifications and addition of redox mediators should be further studied. Approaches in which the microbes are encapsulated in a protective matrix that does not inhibit their electrocatalytic activity, including the ability to perform EET, may prove a viable strategy to expand conditions under which microbial electrocatalysts can operate. Additionally strategies that identify exoelectrogenic organisms able to operate under conditions more beneficial for oxygen reduction at cathodes and/or ion transport through separators, as well as approaches to protect existing exoelectrogenic organisms under such conditions, could have significant impact. Development of cathodes able to operate optimally at neutral $\mathrm{pH}$ and 
separators able to operate optimally at lower temperature could also have significant impact.

Understanding the ins and outs of microbe-electrode electron transfer reactions requires a combined truly inter-disciplinary approach that holds out a promise of improved EET to result in more competitive BES approaches in emerging technologies such as generating energy and chemical feedstocks from waste or renewables.

\section{Conflict of financial interest statement}

\section{We don't have a conflict of financial interest.}

\section{Acknowledgement}

We thank our national and international granting agencies, in particular the $\mathrm{ESBCO}_{2}$ project (PIOF-GA-2011-302964)- an EU Marie Curie International Outgoing Fellowship (MC-IOF) for Career Development to A.K. We are very thankful to Sarah, Lenny Tender and Gregory Stephanopoulos for helpful discussions.

\section{Box 2. A timeline showing evolution of major achievements of microbial catalysis at the bioanode}

1988: First time demonstrations of metal oxide reduction by Geobacter ${ }^{75}$ and Shewanella ${ }^{76}$ via EET. These two literatures initiated the field of bioanode research. 
2002-2003: Foreign electron shuttle can drive long-range EET in both Geobacter and Shewanella biofilms was confirmed experimentally 77,78 .

2005-2010: Series of genetic-based research to reveal the EET function of c-cyts on the outer membrane of Geobacter and Shewanella ${ }^{22,26}$.

2005: First systematic study of Geobacter nanowire. The nanowire based long-range EET was also proposed in this work ${ }^{19}$.

2006: First observation of Shewanella nanowire. The conductivity and the composition of Shewanella nanowire are also analyzed ${ }^{18}$.

2008: Flavin was suggested as the electron shuttle for long range Shewanella $\mathrm{EET}^{20}$.

2008: The application of microbial fuel cell (MFC) as batteries to power up multiple sensors for measuring air temperature, pressure, relative humidity, and water temperature. This work is the first particle application of the MFC system $^{79}$.

2011-current: Two debating models for long-range electron transport in Geobacter nanowire are presented: i). "metallic-like" model conductivity proposes electron transport based on $\Pi-\Pi$ interactions of c-cyts ${ }^{43}$; ii) "superexchange" model the EET is driven by series of redox reactions of ccyts ${ }^{57}$. Many following researches are devoted to provide experimental evidences for each model.

2014-2015 EET current measurements were performed in both single Geobacter ${ }^{72}$ and single Shewanella ${ }^{71}$. Results reveal the EET current of single-bacterium is around $100 \mathrm{fA}$ which help to estimate the maximum current generation of biofilms. 


\section{Box 3. A timeline showing evolution of major achievements towards biocathode applied technologies including microbial electrosynthesis}

2004: Geobacter biofilm shown to harvest electrons directly from biocathode for respiration (1).

2005: Geobacter sulfurreducens biofilm reduces uranium, from soluble U(VI) to insoluble $U(I V)$, showing potential of biocathodes in bioremediation (2)

2009: Mixed consortia biofilm, dominated by Methanobacterium palustre, converts $\mathrm{CO}_{2}$ and current into methane (3).

2010: Pure culture acetogenic Sporomusa ovata biofilm converts $\mathrm{CO}_{2}$ and current directly to acetate (4).

2011: The identification of $\mathrm{PccH}$, a cytochrome essential for cathodic but not for anodic Geobacter sulfurreducens respiration, shows that distinct EET pathways are used by the bacterium depending on electron flow to/from electrode (5).

2011: Shewanella oneidensis shown to utilise MtrABC 'cytochrome-porin' conduit for bi-directional EET (6).

2014: Biofilms of phototrophic bacterium Rhodopseudomonas palustris shown to harvest electrons from electrode using $\mathrm{CO}_{2}$ as sole carbon source/electron acceptor (7).

2014: Genetically engineered Clostridium ljungdahii biofilm converts $\mathrm{CO}_{2}$ and current to butyrate (8). 
2015: Methanogenic Methanococcus maripaludis biofilms shown to secrete proteins which facilitate electron uptake for biocathodic $\mathrm{CO}_{2}$ fixation (9). 


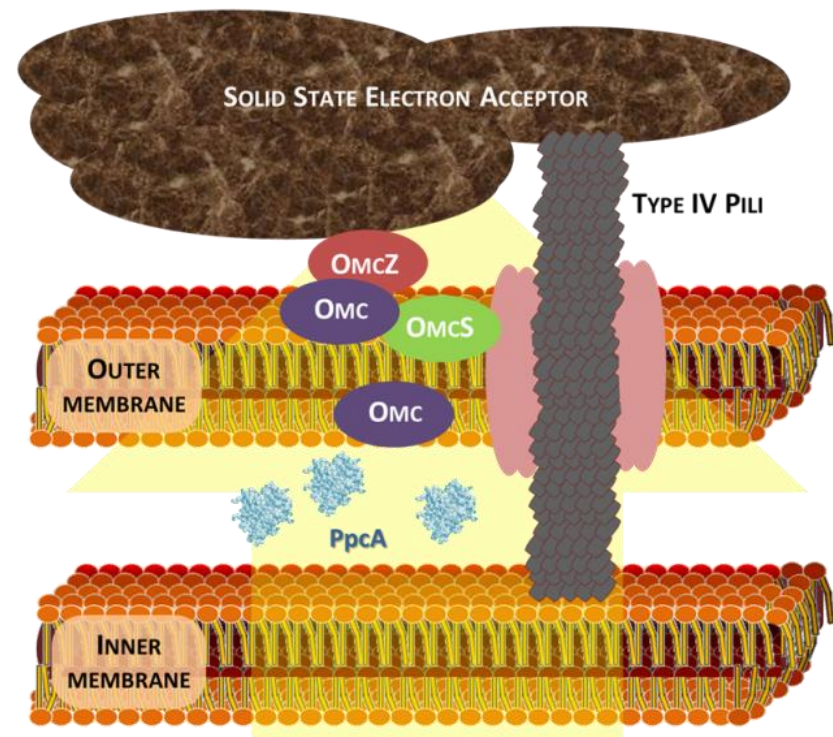

$\mathrm{e}^{-}$

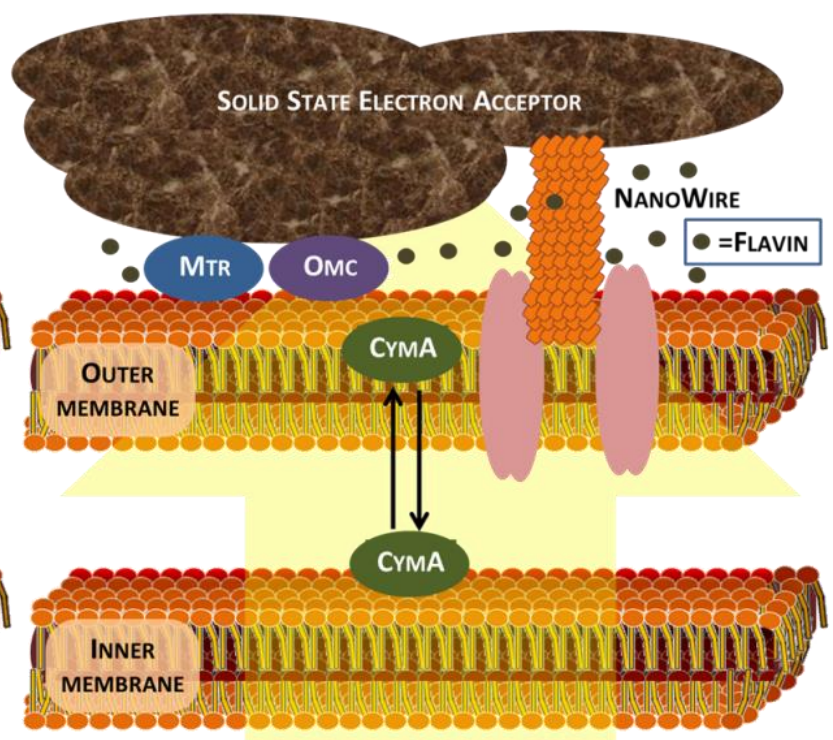

$\mathrm{e}^{-}$

Fig. 1. Schemes of EET in (a) Geobacter and (b) Shewanella; in (a) Geobacter, type iv Pili can directly transport electron from inner membrane to electron acceptor. OmcZ mainly contributes to the outer membrane EET while other OMCs support the EETs of both type iv Pili and OmcZ. In (b) Shewanella the electron generated on inner membrane is transport by CymA to outer membrane then be transported to electron acceptor by MTRs and OMCs to complete EET. The nanowires are considered as the extension of outer membrane and perform EET by electron hopping. Self-excrete Falvin also involved in the EET process as the electron shuttle or cofactors. 


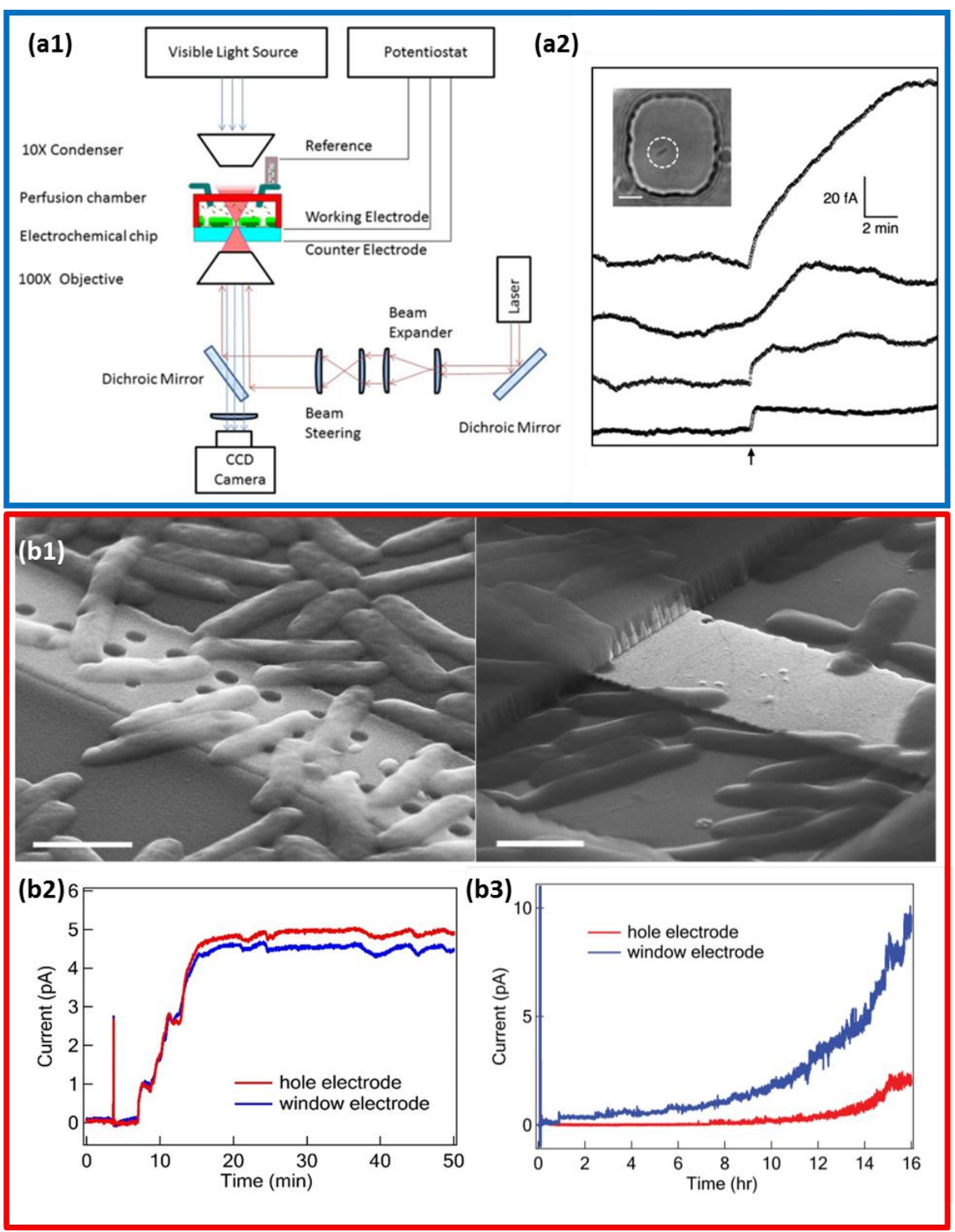

Fig. 2 Micro-scale EET studies: (a) optical tweezers entrapped single Shewanella for in situ EET current measurement: (a1) experimental setup of optical tweezers, perfusion chamber, and electrochemical measurement, (a2) image of entrapped single Shewanella and the EET current measurements (15 $-100 \mathrm{fA}$ ); (b) Probing EET mechanisms of both Shewanella and Geobacter in microscale; (b1) is the images of bacteria on electrodes with nanoholes and window, respectively (Scale bar, $1 \mu \mathrm{m}$ ); (b2) and (b3) are the simultaneously 
short-circuit current measurement on electrodes with nanoholes (red) and large window (blue). The results in (b2) indicate that the mediators dominate the Shewanella EET whereas the current differences between widow and nanoholes electrodes in (b3) demonstrate that the direct connection with electrode can facilitate EET of Geobacter. Reprint with permission ${ }^{70-73}$

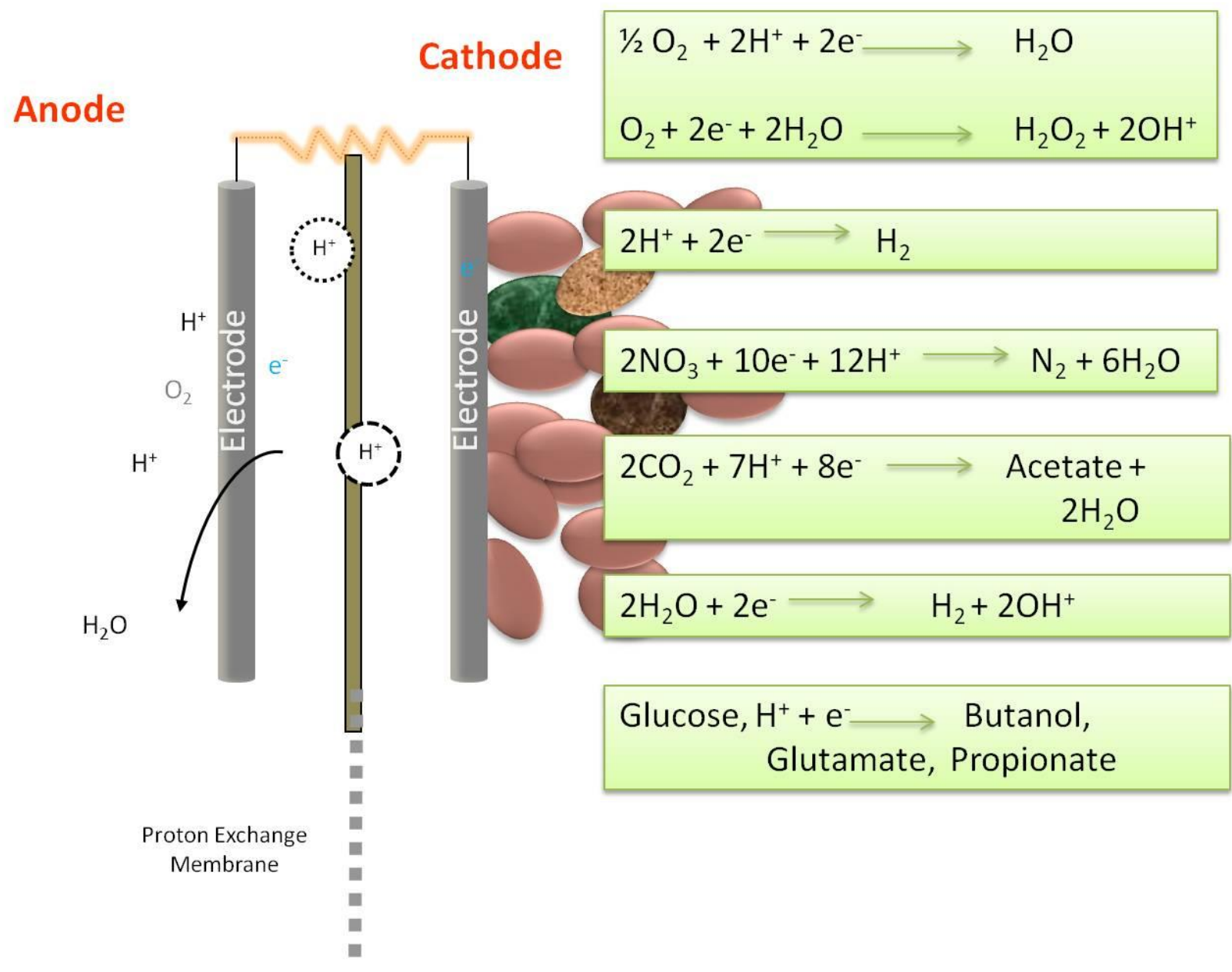

Figure 3. The cathode as an electron donor and the biochemical reactions that lead to the production of products and reactions. 
(a)

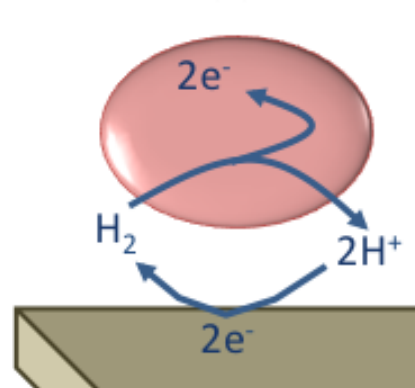

(b)

(c)

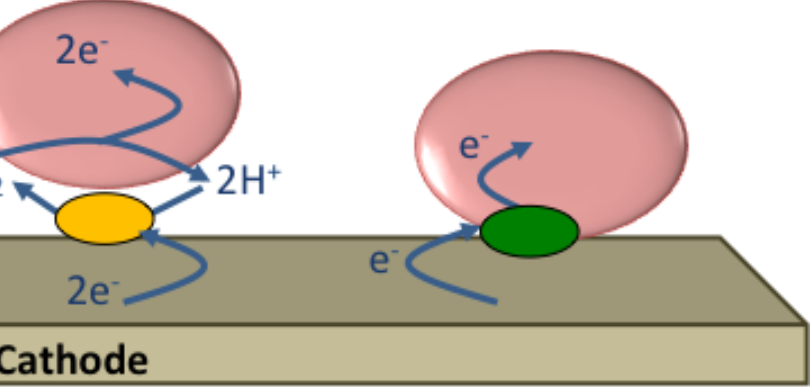

Figure 4. Proposed electron transfer pathways utilised by microbes for extracellular uptake of electrons; (a) scavenging of cathodically generated $\mathrm{H}_{2}$ at electrode surface, (b) uptake of $\mathrm{H}_{2}$ generated by secreted redox proteins e.g. hydrogenases and (c) direct uptake of electrons by outer membrane bound redox proteins e.g. cytochromes. 


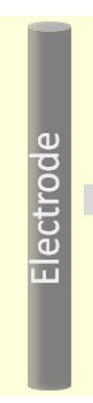

Surface Engineering/Modification

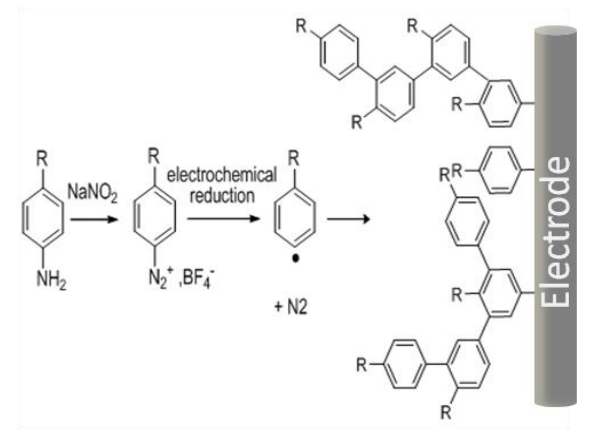

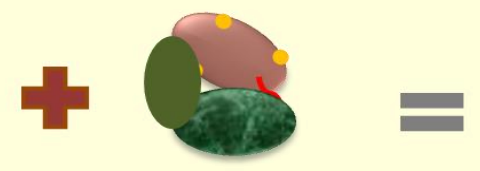

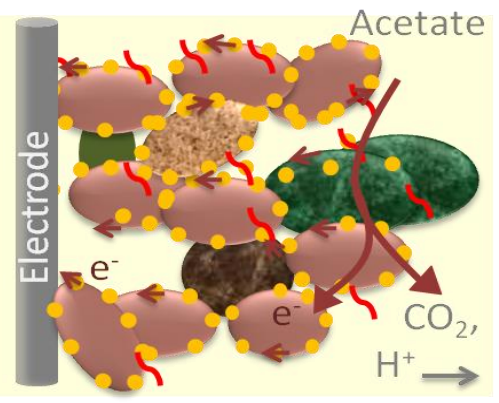

Altered

Electronic Interactions

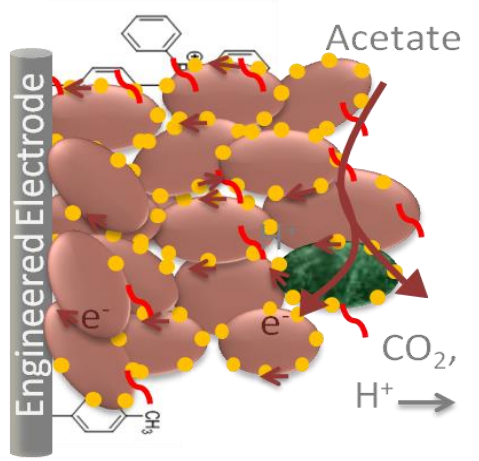

Figure 5. Surface engineering of the microbe-electrode interface alters microbial-electrode interactions for acetate-oxidizing bioanodes. A functional group, $\mathrm{R}$ (where $\mathrm{R}$ is boronic acid, triphenylphosphine, carboxylate, amine, dimethylamine, hydroxyl or methyl groups from top to bottom on the engineered electrode), is grafted over the electrode surface via in-situ diazotization of an arylamine and subsequent electrochemical reduction, providing an engineered electrode with physico-chemical characteristics that can alter microbial-electrode interactions, as described in the text. 


\section{Revised Reference (for Bioanode Section)}

1. Rabaey, K. Bioelectrochemical Systems: From Extracellular Electron Transfer to Biotechnological Application. (IWApublishing, 2009).

2. Logan, B. E. et al. Microbial fuel cells: Methodology and technology. Environ. Sci. Technol. 40, 5181-5192 (2006).

3. Rosenbaum, M. A. \& Franks, A. E. Microbial catalysis in bioelectrochemical technologies: Status quo, challenges and perspectives. Appl. Microbiol. Biotechnol. 98, 509-518 (2014).

4. Wang, H. \& Ren, Z. J. A comprehensive review of microbial electrochemical systems as a platform technology. Biotechnol. Adv. 31, 1796-1807 (2013).

5. Bajracharya, S. et al. An overview on emerging bioelectrochemical systems (BESs): Technology for sustainable electricity, waste remediation, resource recovery, chemical production and beyond. Renew. Energy 98, 153-170 (2016).

6. Schröder, U. Anodic electron transfer mechanisms in microbial fuel cells and their energy efficiency. Phys. Chem. Chem. Phys. 9, 2619-2629 (2007).

7. Mathuriya, A. S. \& Yakhmi, J. V. Microbial fuel cells - Applications for 
generation of electrical power and beyond. Crit. Rev. Microbiol. 7828, 1-17 (2014).

8. Leech, D., Kavanagh, P. \& Schuhmann, W. Enzymatic fuel cells: Recent progress. Electrochim. Acta 84, 223-234 (2012).

9. Habermüller, K., Mosbach, M. \& Schuhmann, W. Electron-transfer mechanisms in amperometric biosensors. Fresenius. J. Anal. Chem. 366, 560-568 (2000).

10. Falk, M., Blum, Z. \& Shleev, S. Direct electron transfer based enzymatic fuel cells. Electrochim. Acta 82, 191-202 (2012).

11. Ghindilis, A. L., Atanasov, P. \& Wilkins, E. Enzyme-catalyzed direct electron transfer: Fundamentals and analytical applications. Electroanalysis 9, 661-674 (1997).

12. Osman, M. H., Shah, A. A. \& Walsh, F. C. Recent progress and continuing challenges in bio-fuel cells. Part I: Enzymatic cells. Biosens. Bioelectron. 26, 3087-3102 (2011).

13. Willner, I. \& Katz, E. Integration of Layered Redox Proteins and Conductive Supports for Bioelectronic Applications. Angew. Chemie 39, 1180-1218 (2000).

14. Moehlenbrock, M. J. \& Minteer, S. D. Extended lifetime biofuel cells. Chem. Soc. Rev. 37, 1188-1196 (2008).

15. Kim, J., Jia, H. \& Wang, P. Challenges in biocatalysis for enzyme-based biofuel cells. Biotechnol. Adv. 24, 296-308 (2006).

16. Potter, M. C. Electrical Effects Accompanying the Decomposition of Organic Compounds. Proc. R. Soc. London. Ser. B, Contain. Pap. a Biol. Character 84, 260 LP-276 (1911). 
17. Barnett, C. The bacterial culture as an electrical half-cell. J. Bacteriol. 21, 18 (1931).

18. Gorby, Y. A. et al. Electrically conductive bacterial nanowires produced by Shewanella oneidensis strain MR-1 and other microorganisms. Proc. Natl. Acad. Sci. U. S. A. 103, 11358-11363 (2006).

19. Reguera, G. et al. Extracellular electron transfer via microbial nanowires. Nature 435, 1098-1101 (2005).

20. Marsili, E. et al. Shewanella secretes flavins that mediate extracellular electron transfer. Proc. Natl. Acad. Sci. U. S. A. 105, 3968-3973 (2008).

21. Newman, D. K. \& Kolter, R. A role for excreted quinones in extracellular electron transfer. Nature 405, 94-7 (2000).

22. Shi, L., Squier, T. C., Zachara, J. M. \& Fredrickson, J. K. Respiration of metal (hydr)oxides by Shewanella and Geobacter: A key role for multihaem c-type cytochromes. Mol. Microbiol. 65, 12-20 (2007).

23. Nealson, K. H. \& Rowe, A. R. Electromicrobiology: realities, grand challenges, goals and predictions. Microb. Biotechnol. 9, 595-600 (2016).

24. Wei, J., Liang, P. \& Huang, X. Recent progress in electrodes for microbial fuel cells. Bioresour. Technol. 102, 9335-9344 (2011).

25. Torres, C. I. et al. A kinetic perspective on extracellular electron transfer by anode-respiring bacteria. FEMS Microbiol. Rev. 34, 3-17 (2010).

26. Yang, Y., Xu, M., Guo, J. \& Sun, G. Bacterial extracellular electron transfer in bioelectrochemical systems. Process Biochem. 47, 1707- 
1714 (2012).

27. Patil, S. A., Hägerhäll, C. \& Gorton, L. Electron transfer mechanisms between microorganisms and electrodes in bioelectrochemical systems. Bioanal. Rev. 4, 159-192 (2012).

28. Lovley, D. R., Coates, J. D., Blunt-Harris, E. L., Phillips, E. J. P. \& Woodward, J. C. Humic substances as electron acceptors for microbial respiration. Nature 382, 445-448 (1996).

29. Roden, E. E. et al. Extracellular electron transfer through microbial reduction of solid-phase humic substances. Nat. Geosci. 3, 417-421 (2010).

30. Mowat, C. G. \& Chapman, S. K. Multi-heme cytochromes-new structures, new chemistry. Dalt. Trans. 3381-3389 (2005). doi:10.1039/B505184C

31. Mehta, T., Coppi, M. V, Childers, S. E. \& Lovley, D. R. Outer Membrane c -Type Cytochromes Required for Fe (III) and Mn (IV) Oxide Reduction in Geobacter sulfurreducens. Appl. Environ. Microbiol. 71, 8634-8641 (2005).

32. Holmes, D. E. et al. Microarray and genetic analysis of electron transfer to electrodes in Geobacter sulfurreducens. Environ. Microbiol. 8, 18051815 (2006).

33. Nevin, K. P. et al. Anode biofilm transcriptomics reveals outer surface components essential for high density current production in Geobacter sulfurreducens fuel cells. PLoS One 4, (2009).

34. Richter, H. et al. Cyclic voltammetry of biofilms of wild type and mutant Geobacter sulfurreducens on fuel cell anodes indicates possible roles of OmcB, OmcZ, type IV pili, and protons in extracellular electron 
transfer. Energy Environ. Sci. 2, 506 (2009).

35. Coursolle, D., Baron, D. B., Bond, D. R. \& Gralnick, J. A. The Mtr respiratory pathway is essential for reducing flavins and electrodes in Shewanella oneidensis. J. Bacteriol. 192, 467-474 (2010).

36. Breuer, M., Rosso, K. M., Blumberger, J. \& Butt, J. N. Multi-haem cytochromes in Shewanella oneidensis MR-1: structures, functions and opportunities. J. R. Soc. Interface 12, 20141117 (2015).

37. Bond, D. R., Strycharz-Glaven, S. M., Tender, L. M. \& Torres, C. I. On Electron Transport through Geobacter Biofilms. ChemSusChem 5, 1099-1105 (2012).

38. Shi, L. et al. Extracellular electron transfer mechanisms between microorganisms and minerals. Nat Rev Micro 14, 651-662 (2016).

39. Malvankar, N. S. \& Lovley, D. R. in Biofilms in Bioelectrochemical Systems: From Laboratory Practice to Data Interpretation (eds. BEYENAL, H. \& BABAUTA, J. T.) 220-222 (John Wiley \& Sons, Inc, 2015).

40. Xu, S., Jangir, Y. \& El-Naggar, M. Y. Disentangling the roles of free and cytochrome-bound flavins in extracellular electron transport from Shewanella oneidensis MR-1. Electrochim. Acta 198, 49-55 (2016).

41. Malvankar, N. S., Rotello, V. M., Tuominen, M. T. \& Lovley, D. R. Reply to 'Measuring conductivity of living Geobacter sulfurreducens biofilms'. Nat Nano 11, 913-914 (2016).

42. Yates, M. D. et al. Measuring conductivity of living Geobacter sulfurreducens biofilms. Nat Nano 11, 910-913 (2016).

43. Malvankar, N. S. \& Lovley, D. R. Microbial nanowires: A new paradigm 
for biological electron transfer and bioelectronics. ChemSusChem 5, 1039-1046 (2012).

44. Malvankar, N. S. et al. Tunable metallic-like conductivity in microbial nanowire networks. Nat. Nanotechnol. 6, 573-579 (2011).

45. Malvankar, N. S., Tuominen, M. T. \& Lovley, D. R. Comment on '"On electrical conductivity of microbial nanowires and biofilms"' by S. M. Strycharz-Glaven, R. M. Snider, A. Guiseppi-Elie and L. M. Tender, Energy Environ. Sci., 2011, 4, 4366. Energy Environ. Sci. 5, 6247-49 (2012).

46. Strycharz-Glaven, S. M. \& Tender, L. M. Reply to the 'Comment on "On electrical conductivity of microbial nanowires and biofilms"' by N. S. Malvankar, M. T. Tuominen and D. R. Lovley, Energy Environ. Sci., 2012, 5, DOI: 10.1039/c2ee02613a. Energy Environ. Sci. 5, 62506255 (2012).

47. Strycharz-Glaven, S. M., Snider, R. M., Guiseppi-Elie, A. \& Tender, L. M. On the electrical conductivity of microbial nanowires and biofilms. Energy Environ. Sci. 4, 4366 (2011).

48. Torres, C. I., Marcus, A. K., Parameswaran, P. \& Rittmann, B. E. Kinetic experiments for evaluating the nernst-monod model for anoderespiring bacteria (ARB) in a biofilm anode. Environ. Sci. Technol. 42, 6593-6597 (2008).

49. Yoho, R. A., Popat, S. C., Rago, L., Guisasola, A. \& Torres, C. I. Anode Biofilms of Geoalkalibacter ferrihydriticus Exhibit Electrochemical Signatures of Multiple Electron Transport Pathways. Langmuir 31, 12552-12559 (2015).

50. Katuri, K. P., Kavanagh, P., Rengaraj, S. \& Leech, D. Geobacter 
sulfurreducens biofilms developed under different growth conditions on glassy carbon electrodes: insights using cyclic voltammetry. Chem. Commun. 46, 4758-60 (2010).

51. Strycharz, S. M. et al. Application of cyclic voltammetry to investigate enhanced catalytic current generation by biofilm-modified anodes of Geobacter sulfurreducens strain DL1vs. variant strain KN400. Energy Environ. Sci. 4, 896-913 (2011).

52. Yates, M. D. et al. Thermally Activated Long Range Electron Transport in Living Biofilms. Phys. Chem. Chem. Phys. 17, 32564-32570 (2015).

53. Snider, R. M., Strycharz-Glaven, S. M., Tsoi, S. D., Erickson, J. S. \& Tender, L. M. Long-range electron transport in Geobacter sulfurreducens biofilms is redox gradient-driven. Proc. Natl. Acad. Sci. 109, 15467-15472 (2012).

54. Schrott, G. D., Bonanni, P. S., Robuschi, L., Esteve-Nuñez, A. \& Busalmen, J. P. Electrochemical insight into the mechanism of electron transport in biofilms of Geobacter sulfurreducens. Electrochim. Acta 56, 10791-10795 (2011).

55. El-Naggar, M. Y., Gorby, Y. a, Xia, W. \& Nealson, K. H. The molecular density of states in bacterial nanowires. Biophys. J. 95, L10-L12 (2008).

56. Pirbadian, S. et al. Shewanella oneidensis MR-1 nanowires are outer membrane and periplasmic extensions of the extracellular electron transport components. Proc. Natl. Acad. Sci. U. S. A. 111, 12883-8 (2014).

57. Pirbadian, S. \& El-Naggar, M. Y. Multistep hopping and extracellular charge transfer in microbial redox chains. Phys. Chem. Chem. Phys. 
14, 13802-8 (2012).

58. Yang, Y. et al. Enhancing Bidirectional Electron Transfer of Shewanella oneidensis by a Synthetic Flavin Pathway. ACS Synth. Biol. 4, 815-823 (2015).

59. Tao, L. et al. Improving mediated electron transport in anodic bioelectrocatalysis. Chem. Commun. 51, 12170-12173 (2015).

60. Yong, X.-Y. et al. Enhancement of bioelectricity generation by manipulation of the electron shuttles synthesis pathway in microbial fuel cells. Bioresour. Technol. 152, 220-224 (2014).

61. Xie, X. et al. Three-Dimensional Carbon Nanotube-Textile Anode for High-Performance Microbial Fuel Cells. Nano Lett. 11, 291-296 (2011).

62. Xie, X. et al. Graphene-sponges as high-performance low-cost anodes for microbial fuel cells. Energy Environ. Sci. 5, 6862-6866 (2012).

63. Ji, J. et al. A layer-by-layer self-assembled Fe2O3 nanorod-based composite multilayer film on ITO anode in microbial fuel cell. Colloids Surfaces A Physicochem. Eng. Asp. 390, 56-61 (2011).

64. Jiang, X. et al. Nanoparticle Facilitated Extracellular Electron Transfer in Microbial Fuel Cells. Nano Lett. 14, 6737-6742 (2014).

65. Kirchhofer, N. D. et al. The conjugated oligoelectrolyte DSSN+ enables exceptional coulombic efficiency via direct electron transfer for anoderespiring Shewanella oneidensis MR-1-a mechanistic study. Phys. Chem. Chem. Phys. 16, 20436-43 (2014).

66. Hou, H. et al. Conjugated oligoelectrolytes increase power generation in E. Coli Microbial fuel cells. Adv. Mater. 25, 1593-1597 (2013).

67. Wang, V. B. et al. Comparison of flavins and a conjugated 
oligoelectrolyte in stimulating extracellular electron transport from Shewanella oneidensis MR-1. Electrochem. commun. 41, 55-58 (2014).

68. Lower, B. H. et al. Specific Bonds between an Iron Oxide Surface and Outer Membrane Cytochromes MtrC and OmcA from Shewanella oneidensis MR-1 . J. Bacteriol. 189, 4944-4952 (2007).

69. Li, Z., Venkataraman, A., Rosenbaum, M. A. \& Angenent, L. T. A laminar-flow microfluidic device for quantitative analysis of microbial electrochemical activity. ChemSusChem 5, 1119-1123 (2012).

70. Choi, S. Microscale microbial fuel cells: Advances and challenges. Biosens. Bioelectron. 69, 8-25 (2015).

71. Gross, B. J. \& El-Naggar, M. Y. A combined electrochemical and optical trapping platform for measuring single cell respiration rates at electrode interfaces. Rev. Sci. Instrum. 86, (2015).

72. Jiang, X. et al. Probing single- to multi-cell level charge transport in Geobacter sulfurreducens DL-1. Nat. Commun. 4, 2751 (2013).

73. Jiang, X. et al. Probing electron transfer mechanisms in Shewanella oneidensis MR-1 using a nanoelectrode platform and single-cell imaging. Proc. Natl. Acad. Sci. 107, 16806-16810 (2010).

74. Hol, F. J. H. \& Dekker, C. Zooming in to see the bigger picture: Microfluidic and nanofabrication tools to study bacteria. Science (80-. ). 346, 1251821-1251821 (2014).

75. Lovley, D. R. \& Phillips, E. J. P. Novel Mode of Microbial EnergyMetabolism - Organic-Carbon Oxidation Coupled To Dissimilatory Reduction of Iron or Manganese. Appl. Environ. Microbiol. 54, 14721480 (1988). 
76. MYERS, C. R. \& NEALSON, K. H. Bacterial Manganese Reduction and Growth with Manganese Oxide as the Sole Electron Acceptor. Science (80-. ). 240, 1319 LP-1321 (1988).

77. Chaudhuri, S. K. \& Lovley, D. R. Electricity generation by direct oxidation of glucose in mediatorless microbial fuel cells. Nat Biotech

21, 1229-1232 (2003).

78. Kim, H. J. et al. A mediator-less microbial fuel cell using a metal reducing bacterium, Shewanella putrefaciens. Enzyme Microb. Technol. 30, 145-152 (2002).

79. Tender, L. M. et al. The first demonstration of a microbial fuel cell as a viable power supply: Powering a meteorological buoy. J. Power Sources 179, 571-575 (2008).

References (Biocathode)

References

1. Weber, K. A.; Achenbach, L. A.; Coates, J. D., Microorganisms pumping iron: anaerobic microbial iron oxidation and reduction. Nature Reviews Microbiology 2006, 4, (10), 752-764.

2. Enning, D.; Garrelfs, J., Corrosion of Iron by Sulfate-Reducing Bacteria: New Views of an Old Problem. Applied and Environmental Microbiology 2014, 80, (4), 1226-1236. 
3. Dinh, H. T.; Kuever, J.; Mussmann, M.; Hassel, A. W.; Stratmann, M.; Widdel, F., Iron corrosion by novel anaerobic microorganisms. Nature 2004, 427, (6977), 829-832.

4. Gregory, K. B.; Bond, D. R.; Lovley, D. R., Graphite electrodes as electron donors for anaerobic respiration. Environmental Microbiology 2004, 6, (6), 596-604.

5. Ross, D. E.; Flynn, J. M.; Baron, D. B.; Gralnick, J. A.; Bond, D. R., Towards Electrosynthesis in Shewanella: Energetics of Reversing the Mtr Pathway for Reductive Metabolism. Plos One 2011, 6, (2).

6. Strycharz, S. M.; Glaven, R. H.; Coppi, M. V.; Gannon, S. M.; Perpetua, L. A.; Liu, A.; Nevin, K. P.; Lovley, D. R., Gene expression and deletion analysis of mechanisms for electron transfer from electrodes to Geobacter sulfurreducens. Bioelectrochemistry 2011, 80, (2), 142-150.

7. Tremblay, P. L.; Zhang, T., Electrifying microbes for the production of chemicals. Frontiers in Microbiology 2015, 6.

8. Strycharz, S. M.; Woodard, T. L.; Johnson, J. P.; Nevin, K. P.; Sanford, R. A.; Loffler, F. E.; Lovley, D. R., Graphite electrode as a sole electron donor for reductive dechlorination of tetrachlorethene by Geobacter lovleyi. Applied and Environmental Microbiology 2008, 74, (19), 5943-5947.

9. Hsu, L.; Masuda, S. A.; Nealson, K. H.; Pirbazari, M., Evaluation of microbial fuel cell Shewanella biocathodes for treatment of chromate contamination. Rsc Advances 2012, 2, (13), 5844-5855.

10. Gregory, K. B.; Lovley, D. R., Remediation and recovery of uranium from contaminated subsurface environments with electrodes. Environmental Science \& Technology 2005, 39, (22), 8943-8947.

11. Williams, K. H.; Bargar, J. R.; Lloyd, J. R.; Lovley, D. R., Bioremediation of uranium-contaminated groundwater: a systems approach to subsurface biogeochemistry. Current Opinion in Biotechnology 2013, 24, (3), 489-497. 
12. Rabaey, K.; Rozendal, R. A., Microbial electrosynthesis - revisiting the electrical route for microbial production. Nature Reviews Microbiology 2010, $8,(10), 706-716$.

13. Nevin, K. P.; Woodard, T. L.; Franks, A. E.; Summers, Z. M.; Lovley, D. R., Microbial Electrosynthesis: Feeding Microbes Electricity To Convert Carbon Dioxide and Water to Multicarbon Extracellular Organic Compounds. Mbio 2010, 1, (2).

14. Nevin, K. P.; Hensley, S. A.; Franks, A. E.; Summers, Z. M.; Ou, J. H.; Woodard, T. L.; Snoeyenbos-West, O. L.; Lovley, D. R., Electrosynthesis of Organic Compounds from Carbon Dioxide Is Catalyzed by a Diversity of Acetogenic Microorganisms. Applied and Environmental Microbiology 2011, 77, (9), 2882-2886.

15. Choi, O.; Kim, T.; Woo, H. M.; Um, Y., Electricity-driven metabolic shift through direct electron uptake by electroactive heterotroph Clostridium pasteurianum. Scientific Reports 2014, 4.

16. Cheng, S. A.; Xing, D. F.; Call, D. F.; Logan, B. E., Direct Biological Conversion of Electrical Current into Methane by Electromethanogenesis. Environmental Science \& Technology 2009, 43, (10), 3953-3958.

17. Deutzmann, J. S.; Sahin, M.; Spormann, A. M., Extracellular Enzymes Facilitate Electron Uptake in Biocorrosion and Bioelectrosynthesis. Mbio 2015, $6,(2)$.

18. Bose, A.; Gardel, E. J.; Vidoudez, C.; Parra, E. A.; Girguis, P. R., Electron uptake by iron-oxidizing phototrophic bacteria. Nature Communications 2014, 5 .

19. Deng, X.; Nakamura, R.; Hashimoto, K.; Okamoto, A., Electron Extraction from an Extracellular Electrode by Desulfovibrio ferrophilus Strain IS5 Without Using Hydrogen as an Electron Carrier. Electrochemistry 2015, 83, (7), 529-531. 
20. Claassens, N. J.; Sousa, D. Z.; dos Santos, V. A. P. M.; de Vos, W. M.; van der Oost, J., Harnessing the power of microbial autotrophy. Nature Reviews Microbiology 2016, 14, (11), 692-706.

21. Ueki, T.; Nevin, K. P.; Woodard, T. L.; Lovley, D. R., Converting Carbon Dioxide to Butyrate with an Engineered Strain of Clostridium ljungdahlii. Mbio 2014, 5, (5).

22. Kavanagh, P.; Leech, D., Mediated electron transfer in glucose oxidising enzyme electrodes for application to biofuel cells: recent progress and perspectives. Physical Chemistry Chemical Physics 2013, 15, (14), 48594869.

References for Box 3

References

1. Gregory, K. B.; Bond, D. R.; Lovley, D. R., Graphite electrodes as electron donors for anaerobic respiration. Environmental Microbiology 2004, $6,(6), 596-604$.

2. Gregory, K. B.; Lovley, D. R., Remediation and recovery of uranium from contaminated subsurface environments with electrodes. Environmental Science \& Technology 2005, 39, (22), 8943-8947.

3. Cheng, S. A.; Xing, D. F.; Call, D. F.; Logan, B. E., Direct Biological Conversion of Electrical Current into Methane by Electromethanogenesis. Environmental Science \& Technology 2009, 43, (10), 3953-3958.

4. Nevin, K. P.; Woodard, T. L.; Franks, A. E.; Summers, Z. M.; Lovley, D. R., Microbial Electrosynthesis: Feeding Microbes Electricity To Convert Carbon 
Dioxide and Water to Multicarbon Extracellular Organic Compounds. Mbio 2010, 1, (2).

5. Strycharz, S. M.; Glaven, R. H.; Coppi, M. V.; Gannon, S. M.; Perpetua, L. A.; Liu, A.; Nevin, K. P.; Lovley, D. R., Gene expression and deletion analysis of mechanisms for electron transfer from electrodes to Geobacter sulfurreducens. Bioelectrochemistry 2011, 80, (2), 142-150.

6. Ross, D. E.; Flynn, J. M.; Baron, D. B.; Gralnick, J. A.; Bond, D. R., Towards Electrosynthesis in Shewanella: Energetics of Reversing the Mtr Pathway for Reductive Metabolism. Plos One 2011, 6, (2).

7. Bose, A.; Gardel, E. J.; Vidoudez, C. ; Parra, E. A.; Girguis, P. R., Electron uptake by iron-oxidizing phototrophic bacteria. Nature Communications 2014, 5 .

8. Choi, O.; Kim, T.; Woo, H. M.; Um, Y., Electricity-driven metabolic shift through direct electron uptake by electroactive heterotroph Clostridium pasteurianum. Scientific Reports 2014, 4.

9. Deutzmann, J. S.; Sahin, M.; Spormann, A. M., Extracellular Enzymes Facilitate Electron Uptake in Biocorrosion and Bioelectrosynthesis. Mbio 2015, $6,(2)$.

\section{Old References}

References

1. Tender, L.M. et al. Harnessing microbially generated power on the seafloor. Nat. Biotechnol. 20, 821-825 (2002). 
This study shows concept of a marine sediment/benthic microbial fuel cell.

2. Logan, B.E. et al. Microbial fuel cells: Methodology and technology. Environ. Sci. Technol. 40, 5181-5192 (2006).

3. Wang, Z. et al. A previously uncharacterized, nonphotosynthetic member of the chromatiaceae is the primary $\mathrm{CO}_{2}$-fixing constituent in a selfregenerating biocathode. Appl. Environ. Microbiol. 81, 699-712 (2015).

An important study providing a detailed genomic and proteomic insight into a self-regenerating, electroautotrophic biocathode for direct electron transfer via a pathway similar to that proposed for iron-oxidizing bacteria from a previously uncharacterized organism.

4. Marshall, C.W., Ross, D.E., Fichot, E.B., Norman, R.S., May, H.D. Electrosynthesis of commodity chemicals by an autotrophic microbial community. Appl. Environ. Microbiol. 78, 8412-8420 (2012).

5. Lovley, D.R. \& Kelly, N.P. Electrobiocommodities: powering microbial production of fuels and commodity chemicals from carbon dioxide with electricity. Curr. Opi. Biotechnol. 24, 385-390 (2013).

6. Sumit, M. et al. A self-assembling self-repairing microbial photoelectrochemical solar cell. Energy Environ. Sci. 2, 292-298 (2009).

7. Nealson, K.H., Belz, A., McKee, B. Breathing metals as a way of life: geobiology in action. Antonie Van Leeuwenhoek Int. J. Gen. Mol.Microbiol. 81, 215-222 (2002).

8. Lovley, D.R. Dissimilatory metal reduction. Ann. Rev. Microbiol. 47, 263290 (1993). 
9. Hartshorne, R.S. et al. Characterization of an electron conduit between bacteria and the extracellular environment. Proc. Natl. Acad. Sci. USA, 106, 22169-22174 (2009).

10. Shi, L. et al. Molecular Underpinnings of Fe(III) Oxide Reduction by Shewanella oneidensis MR-1. Front. Microbial. 3, 50 (2012).

\section{Gralnick, J.A. \& Newman, D.K. Extracellular respiration. Mol. Microbiol. 65, 1-11 (2007).}

12. Pirbadian, S, et al. Shewanella oneidensis MR-1 nanowires are outer membrane and periplasmic extensions of the extracellular electron transport components. Proc. Natl. Acad. Sci. USA, 111, 12883-12888 (2014).

13. Potter M.C. Electrical effects accompanying the decomposition of organic compounds. Proceedings of the Royal Society of London Series B-Containing Papers of a Biological Character 84, 260-276 (1911).

14. Cohen B. The bacterial culture as an electrical half-cell. J. Bacteriol. 21, 18-19 (1931).

15. Bond, D.R., Holmes, D.E., Tender, L.M., Lovely, D.R. Electrode-reducing microorganisms that harvest energy from marine sediments. Science 295, 483-485 (2002).

First demonstration of a power generating marine sediment/benthic microbial fuel cell.

16. Tender, L. M., From mud to microbial electrocatalysts and conductive nanomaterials. MRS Bulletin 36, 800-805 (2011). 
17. Bond, D.R., Strycharz-Glaven, S.M., Tender, L.M., Torres, C.I. On electron transport through Geobacter biofilms. ChemSusChem, 5, 1099-1105 (2012).

18. Allen PM, Allen H, Hill O, \& Walton NJ (1984) Surface modifiers for the promotion of direct electrochemistry of cytochrome c. J. Electro. Chem. Inter. Electrochem. 178, 69-86.

19. El Kasmi, A., Wallace, J.M., Bowden, E.F., Binet, S.M., Linderman, R.J. Controlling interfacial electron-transfer kinetics of cytochrome $c$ with mixed self-Assembled monolayers. J. Am. Chem. Soc. 120, 225-226 (1998).

20. Strycharz-Glaven, S.M. et al. Electron transport through early exponential phase anode-grown Geobacter sulfurreducens biofilms. ChemElectroChem 1, 1957-1965 (2014).

21. Lebedev, N., Strycharz-Glaven, S.M., Tender, L.M. Spatially resolved confocal resonant Raman microscopic analysis of anode-grown Geobacter sulfurreducens biofilms. Chemphyschem 15, 320-327 (2014).

22. Levar $\mathrm{CE}$, Chan $\mathrm{CH}$, Mehta-Kolte $M G$, Bond D.R. An inner membrane cytochrome required only for reduction of high redox potential extracellular electron acceptors. mBio 5, e02034-14 (2014).

\section{This is an important finding on the role of inner membrane cytochrome in EET as previous efforts primarily focused on outer membrane components.}

23. Richter, L.V., Sandler, S.J., Weis, R.M. Two isoforms of Geobacter sulfurreducens PilA have distinct roles in pilus biogenesis, cytochrome localization, extracellular electron transfer, and biofilm formation. J. Bacteriol. 194, 2551-2563 (2012). 
24. Richter, H., Tender, L.M., Nevin, K.P., Lowy, D.A., Lovley, D.R. Electrochemical analysis of electron transfer to graphite anodes in Geobacter sulfurreducens microbial fuel cells. The General Meeting of the American Society for Microbiol. 108, 595-595 (2008).

25. Torres, C.I. et al. A kinetic perspective on extracellular electron transfer by anode-respiring bacteria. FEMS Reviews 34, 3-17 (2010).

26. Kane, A.L., Bond, D.R., Gralnick, J.A. Electrochemical analysis of Shewanella oneidensis engineered to bind gold electrodes. ACS Syn. Biol. 2, 93-101 (2013).

27. Gregoire, K.P., Glaven, S.M., Hervey, J., Lin, BC., Tender, L.M. Enrichment of a high-current density denitrifying microbial biocathode. J. Electrochem. Soc. 161, H3049-H3057 (2014).

28. Finkelstein, D.A., Tender, L.M., Zeikus, J.G. Effect of electrode potential on electrode-reducing microbiota. Environ. Sci. Technol. 40, 6990-6995 (2006).

29. Liu, J.L., Lowy, D.A., Baumann, R.G., Tender, L.M. Influence of anode pretreatment on its microbial colonization. J. Appl. Microbiol. 102,177-183 (2007).

\section{This study show electrode pre-treatment affects microbial composition of bioanode formed in marine sediment.}

30. Logan, B.E. et al. Microbial electrolysis cells for high yield hydrogen gas production from organic matter. Environ. Sci. Technol. 42, 8630-8640 (2008).

31. Clauwaert, P. et al. Combining biocatalyzed electrolysis with anaerobic digestion. Water Sci. Technol. 57, 575-579 (2008). 
32. Tender, L.M. et al. The first demonstration of a microbial fuel cell as a viable power supply: Powering a meteorological buoy. J. Pow. Sour.179, 571-575 (2008).

33. Malvankar, N.S., et al. Tunable metallic-like conductivity in microbial nanowire networks. Nat. Nanotechnol. 6, 573-579 (2011).

This study proposes electron transport through pili via metallic-like biofilm conductivity.

34. Strycharz-Glaven, S.M., Snider, R.M., Guiseppi-Elie, A., Tender, L.M. On the electrical conductivity of microbial nanowires and biofilms. Energy Environ. Sci. 4, 4366-4379 (2011).

This study proposes a redox gradient driven electron transport as an alternative model based on incoherent redox conductivity analogous to that of redox polymers films on electrodes.

35. Snider, R.M., Strycharz-Glaven, S.M., Tsoi, S.D., Erickson, J.S., Tender, L.M. Long-range electron transport in Geobacter sulfurreducens biofilms is redox gradient-driven. Proc. Natl. Acad. Sci. USA, 109, 5467-15472 (2012).

\section{An important study providing experimental evidence for redox driven long-range electron transfer in G. sulfurreducens bioanodes using interdigitated electrode arrays.}

36. Kumar A., Siggins, A., Katuri, K., Flaherty, V.O., Lens, P., Leech, D. Catalytic response of microbial biofilms grown under fixed anode potentials depends on electrochemical cell configuration. Chem. Eng. J. 230, 532-536 (2013). 
37. Kumar, A., Conghaile, O.P., Katuri, K., Lens, P., Leech, D. Arylamine functionalization of carbon anodes for improved microbial electrocatalysis. RSC Adv. 3, 18759-18761 (2013).

38. Gray, H.B. \& Winkler, J.R. Long-range electron transfer. Proc. Natl. Acad. Sci. USA, 102, 3534-3539 (2005).

\section{Millo, D. et al. In situ spectroelectrochemical investigation of} electrocatalytic microbial biofilms by surface-enhanced resonance raman spectroscopy. Ange. Chem. Inter. Ed. 50 2625-2627 (2011).

40. Coursolle, D., Baron, D.B., Bond, D.R., Gralnick, J.A. The Mtr respiratory pathway is essential for reducing flavins and electrodes in Shewanella oneidensis. J. Bacteriol. 192, 467-474 (2009).

41. Degani, Y., Heller, A. Electrical communication between redox centers of glucose-oxidase and electrodes via electrosttically and covalently bound redox polymers. J. Am. Chem. Soc. 111, 2357-2358 (1989).

42. Richter, H. et al. Cyclic voltammetry of biofilms of wild type and mutant Geobacter sulfurreducens on fuel cell anodes indicates possible roles of OmcB, OmcZ, type IV pili, and protons in extracellular electron transfer. Energy Environ. Sci. 2, 506-516 (2009).

43. Strycharz-Glaven, S.M., Tender, L.M. Reply to the 'comment on "on electrical conductivity of microbial nanowires and biofilms' by Malvankar, N.S., Tuominen, M.T., Lovley, D.R. Energy Environ. Sci. 5, 6247-6249 (2012). Energy Environ. Sci. 5, 6250-6255 (2012).

44. Forster, R.J., Walsh, D.A., Mano, N., Mao, F., Heller, A., Modulating the redox properties of an osmium-containing metallopolymer through the supporting electrolyte and cross-linking. Langmuir 20, 862-868 (2004). 
45. Nicholson, R.S., Shain, I. Theory of stationary electrode polarography single scan + cyclic methods applied to reversible irreversible + kinetic systems. Anal. Chem. 36, 706-723 (1964).

46. Robuschi, L. et al. Spectroscopic slicing to reveal internal redox gradients in electricity-producing biofilms. Ange. Chem. Intern. Edi. 52, 925-928 (2013).

47. Liu, Y., Kim, H., Franklin, R. R., Bond, D. R., Linking spectral and electrochemical analysis to monitor c-type cytochrome redox status in living Geobacter sulfurreducens biofilms. ChemPhysChem 12, 2235-2241 (2011).

48. Virdis, B., Harnisch, F., Batstone, D.J., Rabaey, K., Donose, B.C. Noninvasive characterization of electrochemically active microbial biofilms using confocal Raman microscopy. Energy Environ. Sci. 5, 7017-7024 (2012).

49. Strycharz-Glaven, S.M., Tender, L.M., Reply to the 'Comment on "On electrical conductivity of microbial nanowires and biofilms"' by Malvankar, N.S., Tuominen, M.T., Lovley, D.R. Energy Environ. Sci., 2012, 5, DOI: 10.1039/c2ee02613a. Energy Environ. Sci. 5, 6250-6255 (2012).

50. Pirbadian, S., El-Naggar, M.Y., Multistep hopping and extracellular charge transfer in microbial redox chains. Phys. chemis. chem. phy. 14, 1380213808 (2012).

51. Polizzi, N.F., Skourtis, S.S., Beratan, D.N. Physical constraints on charge transport through bacterial nanowires. Faraday Discussions 155, 43-61 (2012). 
52. Leang, C., Qian, X., Mester, T., Lovley, D.R. Alignment of the c-type cytochrome OmcS along pili of Geobacter sulfurreducens. Appl. Environ. Microbiol. 76, 4080-4084 (2010).

53. Rollefson, J.B., Levar, C.E., Bond, D.R. Identification of genes involved in biofilm formation and respiration via mini-Himar transposon mutagenesis of Geobacter sulfurreducens. J. Bacteriol. 191, 4207-4217 (2009).

54. Tremblay, P.L., Zhang, T. Electrifying microbes for the production of chemicals. Front. Microbiol. 6, 201 (2015).

55. Rabaey, K., Rozendal, R.A. Microbial electrosynthesis - revisiting the electrical route for microbial production. Nature Rev. Microbiol. 8, 706-716 (2010).

56. Gregory, K.B., Bond, D.R., Lovley, D.R. Graphite electrodes as electron donors for anaerobic respiration. Environ. Microbiol. 6, 596-604.

57. Strycharz, S.M. et al. Graphite electrode as a sole electron donor for reductive dechlorination of tetrachlorethene by Geobacter lovleyi. Appl. Environ. Microbiol. 74, 5943-5947 (2008).

\section{This study demonstrates the potential of biocathodes in environmental bioremediation.}

58. Rabaey, K. et al. Cathodic oxygen reduction catalyzed by bacteria in microbial fuel cells. The ISME Journal 2, 519-527 (2008).

59. Rosenbaum, M., Aulenta, F., Villano, M., Angenent, L.T. Cathodes as electron donors for microbial metabolism: which extracellular electron transfer mechanisms are involved? Bioresour. Technol. 102, 324-333 (2011). 
60. Kim, T.S., Kim B.H. Electron flow shift in Clostridium acetobutylicum fermentation by electrochemically introduced reducing equivalent. Biotechnol. Lett. 2, 123-128 (1988).

61. Park, D.H., Laivenieks, M., Guettler, M.V., Jain, M.K., Zeikus J.G. Microbial utilization of electrically reduced neutral red as the sole electron donor for growth and metabolite Production. Appl. Environ. Microbiol. 65, 2912-2917 (1999).

62. Bergel, A., Damien, F., Alfonso, M. Catalysis of oxygen reduction in PEM fuel cell by seawater biofilm. Electrochem. Comm. 7, 900904 (2005).

63. Clauwaert, P. et al. Biological denitrification in microbial fuel cells. Environ. Sci. Technol. 41, 3354-3360 (2007).

64. Rozendal, R.A., Jeremiasse, A.W., Hamelers, H.V.M., Buisman, C.J.N. Hydrogen production with a microbial biocathode. Environ. Sci. Technol. 42, 629-634 (2008).

65. Cheng, S., Xing, D., Call, D.F., Logan, B.E. Direct biological conversion of electrical current into methane by electromethanogenesis. Environ. Sci. Technol. 43, 3953-3958 (2009).

66. Nevin, K.P., Woodard, T.L., Franks, A.E., Summers, Z.M., Lovley, D.R. Microbial electrosynthesis: feeding microbes electricity to convert carbon dioxide and water to multicarbon extracellular organic compounds. mBio, 1 , e00103-10 (2010).

This study shows production of acetate and oxo-butyrate from $\mathrm{CO}_{2}$ in an electrochemical reactor using the acetogen Sporomusa ovate. 
67. Summers, Z.M., Gralnick, J.A., Bond, D.R. Cultivation of an obligate $\mathrm{Fe}$ (II)-oxidizing lithoautotrophic bacterium using electrodes. mBio 4, e00420-e00412 (2013).

This study shows growth of Mariprofundus ferrooxydans- the chemolithoautotrophic iron-oxidizing bacterium at a biocathode.

68. Ueki, T., Nevin, K.P., Woodard, T.L., Lovley, D.R. 2014. Converting carbon dioxide to butyrate with an engineered strain of Clostridium Ijungdahlii. mBio 5, e01636-14 (2014).

69. Lohner, S.T., et al. Hydrogenase-independent uptake and metabolism of electrons by the archaeon Methanococcus maripaludis. The ISME Journal 8, 1673-1681 (2014).

70. Deutzmann, J.S., Sahin, M., Spormann, A.M. Extracellular enzymes facilitate electron uptake in biocorrosion and bioelectrosynthesis. mBio 6, e00496-15 (2015).

This is a good study highlighting role of extracellular electrode attached enzymes in electron transfer.

71. Strycharz, S.M. et al. Gene expression and deletion analysis of mechanisms for electron transfer from electrodes to Geobacter sulfurreducens. Bioelectrochem. 80,142-150 (2011).

72. Ross, D.E., Flynn, J.M., Baron, D.B., Gralnick, J.A., Bond, D.R. Towards electrosynthesis in Shewanella: Energetics of reversing the Mtr pathway for reductive metabolism. PLOS ONE 6, e16649 (2011).

73. Bose, A., Gardel, E.J., Vidoudez, C., Parra, E.A., Girguis, P.R. Electron uptake by iron-oxidizing phototrophic bacteria. Nature Comm. 5, 3391 (2014). 
74. Doud, D.F.R. \& Angenent, L.T. Towards electrosynthesis with uncoupled extracellular electron uptake and metabolic growth: enhancing current uptake with Rhodopseudomonas palustris. Environ. Sci. Technol. Lett. 1, 351-355 (2014).

75. Jourdin, L. et al. A novel carbon nanotube modified scaffold as an efficient biocathode material for improved microbial electrosynthesis. J. Mater. Chem. A. 2, 13093-13102 (2014).

76. Dumas, C., Basseguy R., Bergel, A. Electrochemical activity of Geobacter sulfurreducens biofilms on stainless steel anodes. Electrochim. Acta, 53, 5235-5241 (2008).

77. Nercessian, O., Parot, S., Delia, M.L, Bergel, A., Achouak, W. Harvesting electricity with Geobacter bremensis isolated from compost. Plos One, 7, e34216 (2012).

78. Marsili, E., Sun, J., Bond, D.R. Voltammetry and growth physiology of Geobacter sulfurreducens biofilms as a function of growth stage and imposed potential. Electroanalysis 22, 865-874 (2009).

79. Erable, B. et al. Marine aerobic biofilm as biocathode catalyst. Bioelectrochem, 78, 51-56 (2010).

80. Saito, T., Mehanna, M., Wang, X., Cusick, R. D., Feng, Y., Hickner, M.A. \& Logan B.E. Effect of nitrogen addition on the performance of microbial fuel cell anodes. Biores. Technol. 102, 395-398 (2011).

81. Donlan, R.M. Biofilms: microbial life on surfaces. Emerg. Infect. Dis. 8, 881-90 (2002).

This article highlights the influence of the physico-chemical property of a surface (such as electrostatic, 


\section{hydrophobic/hydrophilic and lipophobic/lipophilic nature) on the biofilm formation.}

82. Picot, M., Lapinsonnière, L., Rothballer, M., Barrière, F. Graphite anode surface modification with controlled reduction of specific aryl diazonium salts for improved microbial fuel cells power output. Biosens. Bioelectron. 28, 181-188 (2011).

This study reports that electrode modification results in reduced colonization time and improved electrocatalytic performance observed over un-modified electrodes.

83. Smith, R.A.J., Porteous, C.M., Gane, A.M. Murphy, M.P. Delivery of bioactive molecules to mitochondria invivo. Proc. Natl. Acad. Sci. USA, 100, 5407-5412 (2003)

84. Lapinsonnière, L., Picot, M., Poriel, C. \& Barrière F. Phenylboronic acid modified anodes promote faster biofilm adhesion and increase microbial fuel cell performances. Electroanal. 25, 601-605 (2013).

85. Ding, C.M., Lv, M.L, Zhu, Y., Jiang, L., Liu, H. wettability-regulated extracellular Electron transfer from the Living organism of Shewanella loihica PV-4. Angew. Chen. Int. Ed. 51, 1446-1451 (2015).

86. Prime, K. \& Whitesides, G. Self-assembled organic monolayers: model systems for studying adsorption of proteins at surfaces. Science 252, 1164-1167 (1991).

87. Cracknell, J.A., Vincent, A.K., Armstrong F,A. Enzymes as working or inspirational electrocatalysts for fuel cells and electrolysis. Chem. Rev. 108, 2439-2461 (2008). 
88. Wang, G.X., Bao, W.J., Wanga M., Xia, X.H. Heme plane orientation dependent direct electron transfer of cytochrome $c$ at SAMs/Au electrodes with different wettability. Chem. Comm, 51, 689-692 (2012).

\section{Song, S., Clark, R.A., Bowden, E.F., Tarlov, M.J. Characterization of cytochrome c/alkanethiolate structures prepared by self- assembly on gold. J. Phys. Chem. 97, 6564-6572 (1993).}

90. Hasan, K., Patil, S.A., Leech, D., Hagerhall, C., Gorton, L. Electrochemical communication between microbial cells and electrodes via osmium redox systems. Biochem. Soc. Trans. 40, 1330-1335 (2012).

91. Ghach, W., Etienne, M., Urbanova, V., Jorand, F.P.A., Walcarius, A. Solgel based 'artificial'biofilm from Pseudomonas fluorescens using bovine heart cytochrome $\mathrm{c}$ as electron mediator. Electrochem. Commun. 38, 7174 (2014).

92. Heller, A. Electrical wiring of redox enzymes. Accounts Chem. Res. 23, 128-134 (1990).

93. Gallaway, J.W., Calabrese-Barton, S.A. Kinetics of redox polymermediated enzyme electrodes. J. Am. Chem. Soc. 130, 8527-8536 (2008).

94. Hasan et al. Photo-electrochemical communication between cyanobacteria (Leptolyngbia sp.) and osmium redox polymer modified electrodes. Phys. Chem. Chem. Phys. 16, 24676-24680 (2014).

95. Hamidi, H. et al. Photocurrent generation from thylakoid membranes on osmium-redox-polymer-modified electrodes. Chem. Sus. Chem. 8, 990993 (2015). 
96. Nie, H., Zhang, T., Cui, M., Lu, H., Lovley, D.R., Russell, T.P. Improved cathode for high efficient microbial-catalyzed reduction in microbial electrosynthesis cells. Phys. Chem. Chem. Phys. 15, 14290-14294 (2013).

97. Zhang, T. et al. Improved cathode materials for microbial electrosynthesis. Energy Environ. Sci. 6, 217-224 (2013).

98. Parameswaran, P., Torres, C.I., Lee H.S., Krajmalnik-Brown, R., Rittmann B.E. Syntrophic interactions among anode respiring bacteria (ARB) and non-ARB in a biofilm anode: electron balances. Biotechnol. Bioeng. 103, 513-523 (2009).

99. TerAvest, M.A., Zajdel, T.J., Ajo-Franklin, C.M. The Mtr pathway of Shewanella oneidensis MR-1 couples substrate utilization to current production in Escherichia coli. ChemElectroChem 1,1874-187 (2014).

100. Wang V.B. et al. Improving change collection in Escherichia coli carbon electrode devices with conjugated oligoelectrodes. Phys. Chem. Chemi. Phy. 15, 5867-5872 (2013).

101. Sivakumar, K. et al. Membrane permeabilization undelies the enhancement of extracellular bioactivity in Shewanella oneidensis by a membrane-spanning congugated oligoelectrolyte. Appl. Microbiol. Biotechnol. 98, 9021-9031 (2014).

102. Popat, S.C., Ki, D., Rittmann, B.E., Torres, C.I. Importance of $\mathrm{OH}$-transport from Cathodes in microbial fuel cells. ChemSusChem 5, 1071-1079 (2012).

103. Lebedev, N., Strycharz-Glaven, S.M., Tender, L.M. High resolution AFM and single-cell resonance Raman spectroscopy of Geobacter sulfurreducens biofilms early in growth. Frontiers in Energy Research 2, 34 (2014). 
